\title{
WHY HAVE TRAFFIC FATALITIES DECLINED IN INDUSTRIALIZED COUNTRIES? IMPLICATIONS FOR PEDESTRIANS AND VEHICLE OCCUPANTS
}

\author{
Elizabeth Kopits \\ U.S. EPA - National Center for Environmental Economics \\ Maureen Cropper \\ World Bank
}

World Bank Policy Research Working Paper 3678, August 2005

The Policy Research Working Paper Series disseminates the findings of work in progress to encourage the exchange of ideas about development issues. An objective of the series is to get the findings out quickly, even if the presentations are less than fully polished. The papers carry the names of the authors and should be cited accordingly. The findings, interpretations, and conclusions expressed in this paper are entirely those of the authors. They do not necessarily represent the view of the World Bank, its Executive Directors, or the countries they represent. Policy Research Working Papers are available online at http://econ.worldbank.org.

We would like to thank the World Bank Research Board for funding and the Bank's Road Safety Thematic Group for comments and encouragement. We would also like to thank the following people for their comments and suggestions: Roger Betancourt, Tony Bliss, Jonah Gelbach, Goff Jacobs, Seth Sanders, Richard Scurfield, and Jeff Smith. We appreciate the comments of seminar participants at Resources for the Future and the University of Maryland.

The findings, interpretation, and conclusions expressed in this paper do not necessarily represent the views of the World Bank, its Executive Directors, or the countries they represent, nor do they reflect the views of the U.S. Environmental Protection Agency. No official Agency endorsement should be inferred. 


\section{Abstract}

This paper examines whether the relationship between traffic fatalities and per capita income is the same for different classes of road users and investigates the factors underlying the decline in fatalities per vehicle kilometer traveled (VKT) observed in high-income countries over recent decades. Formal models of traffic fatalities are developed for vehicle occupants and pedestrians. Reduced-form approximations to these models are estimated using panel data for 32 high-income countries over 1964-2002.

The results suggest that the downward-sloping portion of the curve relating traffic fatalities per capita to per capita income is due primarily to improved pedestrian safety. Our more detailed models shed light on some factors influencing pedestrian fatalities per VKT but much of the reduction in pedestrian fatalities remains unexplained; however, increased motorization and a reduction in the proportion of young drivers in the population clearly played a role.

Occupant fatalities, however, do not show a significant decline with income. What does explain declines in occupant fatalities per distance traveled are reductions in alcohol abuse and improved medical services, and a reduction in young drivers. The importance of demographic factors suggests that in countries where young persons (between 15 and 24 years of age) comprise an increasing share of the driving population, adopting policies to improve young driver education and reduce speeds will be crucial. 


\title{
Why Have Traffic Fatalities Declined in Industrialized Countries? Implications for Pedestrians and Vehicle Occupants
}

\author{
Elizabeth Kopits and Maureen Cropper
}

\section{Introduction}

Research suggests that the death rate due to traffic fatalities at first increases as countries develop and motorization increases, but eventually declines as incomes grow and fatalities per vehicle decrease (Kopits and Cropper, 2005). This implies that, if historic trends continue, fatality rates will continue to increase in the developing world for several decades. An important question for policy is whether the relationship between traffic fatalities and income is the same for different classes of road users-i.e., for pedestrians and vehicle occupants. Pedestrians constitute the majority of traffic deaths in developing countries, but a much smaller fraction in industrialized countries (Peden et al., 2004). It is of interest to know whether pedestrian fatalities do indeed decline more rapidly than occupant fatalities as incomes grow and, if so, why this occurs.

The death rate (fatalities/population) for pedestrians and vehicle occupants is, by definition, the product of fatalities per vehicle kilometer traveled (VKT) and kilometers traveled per person. Since VKTs per person rarely decrease over time, it is the decline in fatalities per VKT that must drive a reduction in the death rate due to traffic fatalities. Since 1970 most industrialized countries have experienced a sharp decline in traffic fatalities per VKT and also in the death rate due to traffic fatalities. ${ }^{1}$ In most cases, the percentage decline has been greater for pedestrian than for occupant fatalities. We wish

\footnotetext{
${ }^{1}$ The mean road death rate of the OECD countries has fallen by half since 1970 (from 24 deaths/100,000 persons in 1970 to approximately 12 deaths/100,000 persons in 2000).
} 
to examine why this has occurred and to ask what, if any, are the implications for developing countries.

We accomplish this in two stages: First we examine how pedestrian and occupant fatalities per VKT change with income. Second, we attempt to explain why this occurs by developing theoretical models of pedestrian and occupant fatalities and estimating the models using a richer set of variables. In essence, we augment per capita income by the variables it proxies—-better roads, safer vehicles, improved medical services. We also examine the impact of demographic trends on pedestrian and occupant fatalities. We address these issues using panel data for developed countries: specifically, we estimate models of pedestrian and occupant fatalities per VKT using data from 1963 through 2002 for 32 industrialized countries, nearly all of which are members of the International Road Traffic Accident Database (IRTAD). ${ }^{2}$

Our main results are as follows: When we examine the impact of per capita income growth on fatalities per VKT, it is clear that, for the countries in our dataset, pedestrian fatalities per VKT fell faster with income than occupant fatalities. When a constant income elasticity is assumed, the elasticity of pedestrian fatalities per VKT with respect to income is -0.64 , whereas occupant fatalities per VKT exhibit no statistically significant relationship to income, although they decline significantly over time. When we examine pedestrian fatalities per capita we find that they increase for incomes up to \$13,165 (1996 Intl \$), but decline with income thereafter. Occupant fatalities per capita, which also increase with income up to \$13,165 (1996 Intl \$), show no statistically significant relationship to income at higher income levels. This suggests that the

\footnotetext{
${ }^{2}$ All of the members of IRTAD are members of OECD, with the exception of Slovenia. We have added to the IRTAD countries data for Chile and Israel.
} 
downward-sloping portion of the curve relating traffic fatalities per capita to per capita income (Kopits and Cropper 2005) is due primarily to declines in pedestrian fatalities.

We then use a richer set of variables to explain variation in fatalities per VKT. Theory suggests that pedestrian fatalities per VKT should depend on (a) the likelihood that a vehicle and pedestrian meet; (b) the probability that an accident is not avoided; and (c) the probability that the pedestrian dies, given than an accident occurs. The likelihood that a pedestrian and vehicle meet depends on population size, on the distribution of the population between rural and urban areas, on the size of the vehicle fleet (which affects the amount each person walks), and on the road network. Whether an accident is avoided depends on driver skill and attitude towards risk, alcohol consumption, and on the condition of the vehicle and the road. Whether a pedestrian dies depends on availability of medical services and the health of the pedestrian.

When we use the richer set of variables suggested by our theoretical model, we find that a decline in the proportion of young drivers, declines in alcohol abuse and an increase in the vehicle fleet are all significantly associated with declines in pedestrian fatalities. In contrast, an increase in the proportion of the population living in cities is positively associated with pedestrian fatalities per VKT, as is the proportion of the population over age 65 . The large negative time trend in our models suggests, however, that we have not accounted for all the factors that caused pedestrian fatalities to fall.

Variation in occupant fatalities per VKT is explained by changes in the proportion of drivers under the age of 24 in the population; alcohol abuse (measured by the death rate due to cirrhosis of the liver); the length of the road network; the size of the vehicle 
fleet; and the number of doctors per capita. We also document the importance of seatbelt usage, although this significantly reduces the size of our dataset.

The paper is organized as follows. Section 2 describes the pattern of pedestrian and occupant fatalities in the IRTAD countries over the study period. In section 3 we develop formal models of pedestrian and vehicle occupant fatalities, following Edlin (1999). We estimate two version of these models: one in which all variables are proxied by per capita income (section 4); and a second in which we use a richer set of variables to explain the behavior of pedestrian and occupant fatalities per VKT in industrialized countries between 1964 and 2002 (section 5). Section 6 concludes.

\section{Traffic Fatality Patterns in Industrialized Countries}

This paper focuses on a subset of high-income countries, countries that, from the early 1970s to the present have experienced a decline in traffic fatalities per vehicle kilometer traveled (VKT). The countries, which (with the exception of Chile and Israel) are all members of the OECD's IRTAD database, are listed in Table 1. Between 1970 and 1999, total traffic fatalities declined, on average, by nearly $35 \%$ in most of these countries, while total vehicle kilometers driven increased by over $250 \%{ }^{3}$ Within each country, the decline was more dramatic for the most vulnerable road users: pedestrians and bicyclists. ${ }^{4}$ As shown in Table 1, on average, the number of pedestrian and bicyclist fatalities fell by over $60 \%$ in our sample countries between 1970 and 1999. Occupant fatalities, on the other hand, declined, on average, by $21 \%$ during this period, and even

\footnotetext{
${ }^{3}$ On average, the total number of vehicles increased by over $200 \%$ during this period.

${ }^{4}$ Hereafter, "pedestrian" deaths refers to both pedestrian and bicyclist fatalities resulting from a motor vehicle accident.
} 
increased in some countries. This corresponds to an average $86 \%$ decline in pedestrian fatalities per VKT and an average $76 \%$ decline in occupant fatalities per VKT.

It is likely that part of the decline in pedestrian deaths in developed countries is due to more pedestrians becoming vehicle occupants. In 1970, pedestrians and bicyclists comprised approximately $37 \%$ of the total road deaths but, by 1999 , the fraction of fatalities accounted for by these vulnerable road users had fallen to $26 \%{ }^{5}$ Likewise, part of the decline in occupant fatalities may reflect the movement from two- to four-wheeled vehicles, as well as overall technological improvements in vehicle crashworthiness. Policy-induced behavioral changes influence both the non-motorized road users and vehicle occupants, but to different degrees.

Much of the existing road safety literature is devoted to evaluating the effectiveness of specific safety interventions in reducing the total number of fatalities or fatal accidents using within-country data. Less of the literature looks at how policies and other factors have impacted the fatality risk of different road user groups separately. Studies that do distinguish among road user classes have focused primarily on the impact of seatbelt usage and alcohol control policies (e.g., alcohol taxes, minimum drinking age laws) (Peltzman, 1975; Garbacz, 1990, 1992; Cohen and Einav, 2003; Ruhm, 1996; Lindgren and Stuart, 1980; Zlatoper, 1984). ${ }^{6}$ They have not addressed the importance of other technological factors (such as improvements in road design and medical services)

\footnotetext{
${ }^{5}$ On average, bicyclist deaths account for approximately $18 \%$ of the total "pedestrian" fatalities in many OECD countries over the sample period. The percentage is as high as 38\% in Sweden, Finland, Denmark, and Belgium, however, and nearly $60 \%$ in the Netherlands.

${ }^{6}$ Research on the effectiveness of seatbelts often focuses on vehicle occupant or driver fatalities only (Evans and Graham, 1991; Sen, 2001). Some studies examining the role of alcohol even restrict attention to certain age classes (Asch and Levy, 1987; Dee, 1999; Dee and Evans, 2001). Peltzman's analysis has also been extended to a few countries in Asia, such as Taiwan (Garbacz 1989), New Zealand (Garbacz 1991, Scuffman and Langley, 2002; Scuffman, 2003), and Japan (McCornac 1993). Finally, analogous to seatbelt use by vehicle occupants, the effect of motorcycle helmet laws and use on motorcycle fatality risk has also been studied (Sass and Zimmerman, 2000; Branas and Knudson, 2001).
} 
or explored the differential effect that demographic trends may have across road user types.

The studies relying on within country data (often over relatively short time periods) are also limited in their ability to assess the relative contributions of different sets of factors to the historic decline in fatality risk. For example, the effect of changes in the motorization rate and changes in the composition of the vehicle fleet are difficult to capture without country-level panel data. This is also true for demographic factors: in virtually every country in the world the death rate due to traffic crashes is higher for persons 15-24 than for any other age group. Whether this reflects inexperience or low risk aversion, it suggests that demographic changes are likely to affect the crash fatality rate, an effect that can be studied using country-level panel data. Country-level panel data can also be used to examine factors such as medical services, which may well impact pedestrian and vehicle occupant accident victims differently. The handful of studies that have used cross-country panel data focused on explaining variation in the total number of fatalities only (Noland, 2003; Page, 2001).

To better understand how the death rate due to traffic accidents varies across road user groups, it is useful to develop a formal model of traffic fatalities, with separate equations for pedestrian and occupant fatalities.

\section{Models of Pedestrian and Occupant Fatalities}

The expected number of traffic deaths occurring in a country each year is the product of the expected number of accidents times the probability that an accident results in a fatality. In section 3.1, we develop separate equations for the expected number of 
vehicle occupant accidents and pedestrian accidents occurring annually. Section 3.2

models the likelihood that an accident results in a fatality. Implications of the models are summarized in section 3.3.

\subsection{Models of Motor Vehicle Accidents}

To model the number of motor vehicle accidents, we follow Edlin's (1999)

derivation of the probability that vehicle $\mathrm{i}$ is involved an accident with another vehicle, $\mathrm{p}_{\mathrm{i}}$, and the probability that vehicle $\mathrm{i}$ is involved in a one-vehicle accident (for example, hitting a tree), $\mathrm{r}_{\mathrm{i}}{ }^{7}$ The expected number of occupant accidents occurring annually is the sum over all vehicles of $p_{i}+r_{i}$.

Following Edlin, the probability that vehicle $i$ has an accident with vehicle $j$ is the probability that both vehicles are in the same location at the same time, and that neither driver avoids an accident. Formally,

$$
P(i \text { has an accident with } \mathrm{j})=\mathrm{f}_{\mathrm{i}} \mathrm{f}_{\mathrm{j}} \mathrm{L}^{-1} \mathrm{q}_{\mathrm{i}} \mathrm{q}_{\mathrm{j}}
$$

where $f_{i}=$ probability that vehicle $i$ is on the road;

$$
\begin{aligned}
& \mathrm{L}=\text { number of locations at which an accident may occur; } \\
& \mathrm{q}_{\mathrm{i}}=\text { probability that the driver of vehicle } \mathrm{i} \text { does not avoid an accident. }
\end{aligned}
$$

$\mathrm{f}_{\mathrm{i}} \mathrm{f}_{\mathrm{j}} \mathrm{L}^{-1}$ is thus the probability that vehicle $\mathrm{j}$ is in the same location as vehicle $\mathrm{i},{ }^{8}$ and $\mathrm{q}_{\mathrm{i}} \mathrm{q}_{\mathrm{j}}$ the probability that neither driver avoids an accident. ${ }^{9}$ Following Edlin, we assume that $f_{i}$

\footnotetext{
${ }^{7}$ Single vehicle crashes account for a substantial portion of fatal crashes and cannot be ignored in modeling. In the U.S., over $50 \%$ of fatal crashes result from single vehicle accidents (U.S. DOT, http://www-fars.nhtsa.dot.gov/report.cfm?stateid=0\&year=2000\&title=Trends). Single-vehicle run-offroadway accidents account for approximately one third of all U.S. highway fatalities (Lee and Mannering, 2002).

${ }^{8} \mathrm{~L}$ is not squared in this expression since it does not matter where on the road the two vehicles meet. The probability that vehicle $i$ is in any location on the road is $f_{i}$. The probability that vehicle $j$ will then be in the same location as $\mathrm{i}$ is equal to the probability that vehicle $\mathrm{j}$ is on the road, $\mathrm{f}_{\mathrm{j}}$, times the probability that $\mathrm{j}$ is at the same location as vehicle $\mathrm{i}, 1 / \mathrm{L}$.

${ }^{9}$ This specification makes the simplifying assumption that accident rates and vehicle locations are both uniform.
} 
is proportional to the number of kilometers that vehicle $i$ is driven annually, $m_{i}$, (i.e., $f_{i}=$ $\rho \mathrm{m}_{\mathrm{i}}$ ) and that $\mathrm{L}$ is proportional to the length of the road network, $\mathrm{R}$.

The probability that vehicle $\mathrm{i}$ is involved in an accident with any other vehicle is

$$
\mathrm{p}_{\mathrm{i}}=\rho \mathrm{m}_{\mathrm{i}} \mathrm{q}_{\mathrm{i}} \mathrm{L}^{-1}\left[\Sigma_{\mathrm{j} \neq \mathrm{i}} \rho \mathrm{m}_{\mathrm{j}} \mathrm{q}_{\mathrm{j}}\right] .
$$

Assuming for simplicity that all drivers are identical, i.e., $q_{i}=q_{j}=q$, the probability that vehicle $\mathrm{i}$ is involved in a two-vehicle accident is given by

$$
\mathrm{p}_{\mathrm{i}} \approx \rho^{2} \mathrm{q}^{2} \mathrm{~m}_{\mathrm{i}} \mathrm{L}^{-1} \mathrm{M}
$$

where $\mathrm{M}=$ total kilometers traveled by all vehicles annually.

The probability that vehicle $\mathrm{i}$ is involved in a one-vehicle accident is the probability that vehicle $\mathrm{i}$ is in a given location $\left(\mathrm{f}_{\mathrm{i}} / \mathrm{L}\right)$, that an event occurs to precipitate an accident (e.g., an unforeseen bend in the road), and that the driver of vehicle $\mathrm{i}$ does not avoid the accident. Denote the probability of the event that precipitates the accident e. Then the probability that vehicle $\mathrm{i}$ is involved in a one-vehicle accident is

$$
\mathrm{r}_{\mathrm{i}}=\rho \mathrm{qm}_{\mathrm{i}} \mathrm{L}^{-1} \mathrm{e} .
$$

The probability of a pedestrian accident may be derived analogously to the probability of a two-vehicle accident. ${ }^{10}$ It is the probability of pedestrian $j$ and vehicle $i$ being in the same place at the same time and neither avoiding the accident:

$$
\begin{aligned}
& P(\text { Pedestrian } \mathrm{j} \text { in an Accident with Vehicle } \mathrm{i})=\mathrm{f}_{\mathrm{i}} \mathrm{f}_{\mathrm{j}} \mathrm{L}^{-1} \mathrm{q}_{\mathrm{i}} \mathrm{q}_{\mathrm{j}} \\
& =\rho \mathrm{m}_{\mathrm{i}} \rho^{\prime} \mathrm{w}_{\mathrm{j}} \mathrm{L}^{-1} \mathrm{qe}^{\prime}
\end{aligned}
$$

where $f_{j}$ is assumed proportional to the number of kilometers pedestrian $j$ walks each year, $\mathrm{w}_{\mathrm{j}}$, and $\mathrm{e}^{\prime}$ is the probability that the pedestrian does not avoid the accident. The

\footnotetext{
${ }^{10}$ For ease of notation, the probability that a driver is unable to avoid a one-vehicle accident or an accident with a pedestrian is assumed the same as the probability that the driver is unable to avoid a two-vehicle accident, $\mathrm{q}_{\mathrm{i}}$.
} 
probability of vehicle $\mathrm{i}$ being involved in a pedestrian accident is the sum across all pedestrians of (5),

(6) $\quad \mathrm{P}($ Vehicle i has an Accident with a Pedestrian $)=\rho \mathrm{m}_{\mathrm{i}} \rho^{\prime} \mathrm{WL}^{-1} \mathrm{qe}^{\prime}$ where $\mathrm{W}$ is the number of kilometers walked by all pedestrians in a year.

The number of pedestrian accidents occurring annually is the sum across all vehicles of (6). Assuming $\mathrm{m}_{\mathrm{i}}=\mathrm{m}$, the average number of kilometers driven per vehicle and noting that $\mathrm{M}=\mathrm{mV}$, where $\mathrm{V}$ is the number of vehicles in the country,

(7) Pedestrian Accidents $=\rho \mathrm{M}^{\prime} \mathrm{WL}^{-1} \mathrm{qe}^{\prime}$

The number of accidents involving vehicle occupants is the sum across all vehicles of (3) and (4):

(8) Occupant Accidents $=\rho^{2} q^{2} M^{2} L^{-1}+\rho q M L^{-1} e$.

\subsection{Models of Accident Fatalities}

The expected number of deaths that occur each year as a result of motor vehicle accidents equals the sum across all vehicles of the probability that an accident occurs times the probability of a fatality, given that an accident occurs. Letting $\gamma=\mathrm{P}(\mathrm{Pedestrian}$ is killed $\mid$ Accident $)$ and $\lambda=\mathrm{P}($ Occupant is killed $\mid$ Accident $)$,

(9) Occupant Fatalities $=\left(\rho^{2} \mathrm{qM}^{2} \mathrm{~L}^{-1}+\rho \mathrm{qML} \mathrm{L}^{-1} \mathrm{e}\right) \lambda$

(10) Pedestrian Fatalities $=\rho \mathrm{M}^{\prime} \mathrm{WL}^{-1} \mathrm{qe}^{\prime} \gamma$.

Expressing (9) and (10) in terms of fatalities per distance traveled by all motor vehicles ( where distance traveled $=\mathrm{M})$,

(9') Occupant Fatalities/Distance Traveled $=\rho^{2} \mathrm{q}^{2} \mathrm{ML}^{-1} \lambda+\rho \mathrm{qL}^{-1} \mathrm{e} \lambda$

$\left(10^{\prime}\right) \quad$ Pedestrian Fatalities/Distance Traveled $=\rho \rho^{\prime} \mathrm{WL}^{-1} \mathrm{qe}^{\prime} \gamma$. 


\subsection{Implications of the Models}

Equation $\left(10^{\prime}\right)$ says that pedestrian fatalities per VKT should decline the more likely it is that a driver can avoid an accident (the smaller is q), the more extensive the road network (the larger is $\mathrm{L}$ ), the less likely a pedestrian is to precipitate the accident (the smaller is $\mathrm{We}^{\prime}$ ), and the less likely the pedestrian is to die if an accident occurs (the smaller is $\gamma$ ). The number of occupant fatalities per VKT (equation $\left(9^{\prime}\right)$ ) should also decline with decreases in $\mathrm{q}$ and with increases in $\mathrm{L}$. In addition, the occupant fatality rate should decline the less likely an event occurs to precipitate a one-vehicle accident (the smaller is e) and the less likely an occupant is to die given that an accident occurred (the smaller is $\lambda$ ). Finally, increases in the total VKTs will increase the probability of any two vehicles meeting on the road and, hence, increase the occupant fatality rate.

\section{How Do Pedestrian and Occupant Fatalities per VKT Vary with Income?}

The models of pedestrian and occupant fatalities per VKT are estimated in two stages: first, the relationship between fatalities per distance traveled and income is examined for pedestrians and occupants separately, then $\left(9^{\prime}\right)$ and $\left(10^{\prime}\right)$ are approximated with flexible, reduced-form functions of variables influencing $\mathrm{q}, \mathrm{e}, \mathrm{L}, \lambda, \gamma$.

Virtually all of the factors that should cause pedestrian fatalities per VKT (equation $\left(10^{\prime}\right)$ ) to fall should increase with income; hence pedestrian fatalities per VKT should decline with economic growth. In contrast, equation $\left(9^{\prime}\right)$ indicates that fatalities per VKT associated with two-vehicle crashes (the second term in $\left(9^{\prime}\right)$ ) should increase with total VKTs. This suggests that occupant fatalities per VKT need not decline 
monotonically with economic growth, nor should they decline as rapidly with per capita income as pedestrian fatalities per VKT.

Table 2 bears this out. The table presents fixed-effects models of $\ln ($ Pedestrian Fatalities/VKT) and $\ln ($ Occupant Fatalities/VKT) estimated using data for 1963-2002 for the countries in Table 3. ${ }^{11}$ Model 1 contains only the log of per capita income (measured in 1996 International \$) and a time trend. The log of income enters model 2 in a piecewise-linear fashion, with each spline segment containing an equal number of observations, while in model $3 \ln ($ Pedestrian Fatalities/VKT) is a quadratic function of the $\log$ of per capita income. ${ }^{12}$

The models for pedestrian fatalities per VKT suggest that fatality risk to pedestrians declines with per capita income, at least until a per capita income of $\$ 20,700$ (1996 Intl \$). ${ }^{13}$ In contrast, the table suggests that there is no monotonic relationship between per capita income and occupant fatality risk, at least over the range of incomes in the data. For pedestrians, fatality risk declines with income for per capita incomes between $\$ 4,552$ and $\$ 20,700$ (1996 Intl \$), with the elasticity of pedestrian fatality risk with respect to income ranging from -0.71 to -1.1 . The only income range in which occupant fatality risk declines with income is $\$ 13,165$ to $\$ 16,565$ (1996 Intl $\$$ ), and the

\footnotetext{
${ }^{11}$ Data sources are described in Appendix A.

${ }^{12}$ In all specifications shown in Table 2, Durbin-Watson statistics (calculated using a STATA program (xtdw) written for calculating DW statistics in fixed effects panel data models (Nunziata (2002), following Baltagi (1995), page 94) indicate the presence of positive within-panel serial correlation in the disturbances. Therefore, the standard errors shown in parentheses under each coefficient have been adjusted to account for serial correlation in disturbances within countries over time, as well as for heteroskedasticity. This procedure is theoretically justified when the number of panels is large (Liang and Zeger, 1986). Recent studies of finite sample properties of robust variance matrix estimators find that this estimator works reasonably well in the context of fixed effects estimation and panel data even when the number of panels is not especially large relative to the length of each panel (Wooldridge, 2003).

${ }^{13}$ This corresponds to the per capita income of Sweden in 1990 and the United States in 1980.
} 
quadratic function suggests that occupant fatality risk rises for incomes in excess of $\$ 25,500$, although the function is fairly flat. ${ }^{14}$

These results suggest that the decline in the death rate (fatalities/population) due to traffic fatalities with income at high income levels (Kopits and Cropper 2005) is dominated by a decline in the pedestrian death rate. This is borne out by Model 4 in Table 2, which correlates the log of the pedestrian and occupant death rates with spline functions of log income. The elasticity of the pedestrian death rate with respect to income is positive for incomes below $\$ 13,165$ (1996 Intl \$) and negative and significant

for incomes in excess of this amount, a result similar to Kopits and Cropper (2005). ${ }^{15}$ In contrast, the elasticity of the occupant death rate with respect to income, which is also positive for incomes below $\$ 13,165$, shows no statistically significant relationship with income for incomes above this level.

\section{What Other Factors Explain Variation in Pedestrian and Occupant Fatality}

\section{Risk?}

We next approximate the models in section 3 with flexible, reduced-form functions of vehicle occupant and pedestrian fatalities per VKT. Given the multiplicative nature of equations $\left(9^{\prime}\right)$ and $\left(10^{\prime}\right)$, models of Occupant Fatalities/VKT (OccF/VKT) and Pedestrian Fatalities/VKT (PedF/VKT) are estimated in log-log form:

$$
\begin{aligned}
& \ln (\mathrm{OccF} / \mathrm{VKT})_{\mathrm{it}}=\mathrm{a}_{\mathrm{i}}+\mathrm{b}_{1} \ln (\mathrm{q})_{\mathrm{it}}+\mathrm{b}_{2} \ln (\mathrm{e})_{\mathrm{it}}+\mathrm{b}_{3} \ln (\lambda)_{\mathrm{it}}+\mathrm{b}_{4} \ln \left(\mathrm{L}_{\mathrm{it}}\right)+ \\
& \mathrm{b}_{5} \ln \left(\mathrm{VEH}_{\mathrm{it}}\right)+\mathrm{ct}+\varepsilon_{\mathrm{it}}
\end{aligned}
$$

\footnotetext{
${ }^{14}$ This coincides with the incomes of Switzerland and the U.S. in the early 1960's.

${ }^{15}$ Kopits and Cropper model the log of the traffic fatality death rate as a spline function of per capita income measured in 1985 international dollars. They find that the death rate declines after incomes of about $\$ 8,600$ (1985 Intl \$). A per capita income of $\$ 13,165$ (1996 Intl \$) is approximately equal to $\$ 8,600$ (1985 Intl \$) for Denmark and Luxembourg in 1965.
} 


$$
\begin{aligned}
& \ln (\operatorname{PedF} / \mathrm{VKT})_{\text {it }}=\mathrm{a}_{\mathrm{i}}+\mathrm{b}_{1} \ln (\mathrm{q})_{\mathrm{it}}+\mathrm{b}_{2} \ln \left(\mathrm{e}^{\prime}\right)_{\mathrm{it}}+\mathrm{b}_{3} \ln (\gamma)_{\mathrm{it}}+\mathrm{b}_{4} \ln \left(\mathrm{L}_{\mathrm{it}}\right)+\mathrm{b}_{5} \ln \left(\mathrm{W}_{\mathrm{it}}\right) \\
& +\mathrm{ct}+\varepsilon_{\mathrm{it}}
\end{aligned}
$$

where $\mathrm{L}, \mathrm{q}, \mathrm{e}, \mathrm{e}^{\prime}, \mathrm{W}, \gamma$, and $\lambda$ are proxied by the variables described below. ${ }^{16}$

\subsection{Specification of Occupant Fatalities per VKT}

The Base Model for occupant fatalities in Table 7 includes three sets of variables in addition to per capita income $(\mathrm{Y})$ and a time trend $(\mathrm{t})$ : demographic variables (YOUTH ELDERLY and URBAN), motorization variables (VEH, VEH*t and VEHGROWTH) and road infrastructure $(\mathrm{RD}$ and $\mathrm{RD} * \mathrm{t})$.

The percent of the driving age population between 15 and 24 (YOUTH), and the percent of the population over 64 (ELDERLY) may influence the probability that a driver avoids an accident (q) as well as the likelihood that an occupant survives a crash ( $\lambda$ ). In practice, q, the probability that a driver avoids an accident reflects driver skill, attitudes towards risk/safety, education, and driving experience, all of which may vary with age. Because attitudes towards risk and level of education may vary with per capita income, we interact YOUTH and Y. The effect on fatality rates of having more older drivers on the road is unclear: although older drivers may have more experience and drive at slower speeds, they may a have a slower reaction time to an imminent collision (thus increasing q). Older drivers may also be less likely to survive a crash (thus affecting $\lambda$ ).

The percent of the population living in urban areas (URBAN) may proxy average speeds, which are likely to be lower in urban than in rural areas, other things equal.

\footnotetext{
${ }^{16}$ Note that the number of vehicles (VEH) enters equation (11) directly from the formal model of Occupant Fatalities/VKT (equation $\left(9^{\prime}\right)$ ).
} 
The size of the vehicle fleet (VEH) should be included in models of occupant fatalities since an increase in VEH, other things equal, should increase the chance of multiple-vehicle crashes. The condition of the vehicle fleet will affect the likelihood that a driver avoids an accident (q). We proxy safer vehicles by interacting the vehicle fleet with time $\left(\mathrm{VEH}^{*} \mathrm{t}\right)$, on the grounds that as older vehicles go out of service, the vehicle mix is tilted toward more recent model year vehicles, which are equipped with better safety features. Hence, holding the size of the vehicle fleet constant, increases in the vehicle-time interaction indicates an increase in the average safety level of the vehicle stock. The rate of growth in the vehicle fleet (VEHGROWTH) is included as a measure of driver experience. The faster the fleet grows, the greater is the proportion of lessexperienced drivers on the road; hence the average driver's inability to avoid collisions (q) should increase with VEHGROWTH.

The model of section 3 suggests that there should be fewer accidents, other things equal, the longer is the road network. We therefore include the total number of routekilometers in the road network (RD) in our models. ${ }^{17}$ Since road designs have improved over time, we include a road length-time trend interaction $\left(\mathrm{RD}^{*} \mathrm{t}\right)$ to capture safer road conditions. If improvements in road design allow drivers more reaction time, this should increase a driver's ability to avoid an imminent accident. Of course, any beneficial effect of improved road and vehicle conditions could be offset by increased speeds or other risky driving behavior, a point to which we return below.

Subsequent models in Table 7 add four additional factors that may affect occupant fatalities: physicians per capita, measures of alcohol consumption/abuse, and the percent

\footnotetext{
${ }^{17}$ Although the number of lane-miles would be a better indicator of the size of the road infrastructure, limited data availability prevents us from using this measure in the analysis.
} 
of two-wheelers in the vehicle fleet. The probability of a vehicle occupant dying given that an accident occurs, $\lambda$, clearly depends on the quality of emergency medical services. Since indicators of emergency medical services are limited, we proxy medical quality by the number of licensed physicians per person (PHYSICIANS). A driver's ability to avoid an accident is clearly influenced by alcohol consumption/abuse. One crude proxy for the amount of drunk driving is the adult (18 years old and over) per capita alcohol consumption in the country (ALCOHOL). Another measure that might give a better indication of the amount of abusive drinking in the country is the death rate due to cirrhosis of the liver (LIVER). The percent of two-wheelers in the vehicle fleet (2WHEELERS) provides some measure of the heterogeneity of the vehicle mix and/or variance of speed on the road.

\subsection{Specification of Pedestrian Fatalities per VKT}

The Base Model for pedestrian fatalities per VKT in Table 8 contains variables identical to those in the model of occupant fatalities, but adds population (POP). Population is included because total kilometers walked by pedestrians (W) should increase with population size. The rationale for including the size of the vehicle fleet in the pedestrian equation is that, holding population constant, $\mathrm{W}$ should vary inversely with VEH. URBAN is included to capture the fact people are more likely to walk in urban areas. 


\section{3. $\quad$ Reduced-Form Estimates}

Tables 7 and 8 summarize the results of estimating various specifications of equations (11) and (12) for both occupant and pedestrian fatalities. They exclude seatbelt variables, which should affect $\lambda^{18}$ but drastically reduce our sample size. Results including the seatbelt variables are presented and discussed in Appendix B.

\section{3.a. Factors Affecting the Occupant Fatality Rate}

In Table 7, which presents the occupant fatality models, several results stand out. Consistent with Table 2, per capita income is insignificant in explaining the decline in occupant fatalities $/ \mathrm{VKT}^{19}$; however, the time trend is also insignificant. What is significant in explaining the decline in occupant fatalities are demographic trends, reductions in alcohol abuse, growth in the road network, improvements in motor vehicles and in the availability of medical services.

Demographic trends. A striking result of Table 7 is the importance of demographic trends. An increase in the percentage of driving age population between 15-24 (YOUTH) has a large, positive effect on the occupant fatality rate. Evaluated at the Base Model (Model 1) sample mean of income, the elasticity with respect to YOUTH is statistically significant across all specifications, ranging in magnitude from 0.608 (0.258) (Model 1) to $0.870(0.291)$ (Model 3). The magnitude of the reduction in YOUTH over the period 1970-2000 (reductions from 20\%-40\%) suggests that this

\footnotetext{
${ }^{18}$ Seatbelt usage has been estimated to increase the probability of crash survival by $50-60$ percent (Evans, 1986).

${ }^{19}$ Note that a linear combination of significant coefficients can be statistically insignificant, and vice versa. In Table 7, for example, although the coefficients on income and the income-YOUTH interaction terms are statistically significant, the variance of the income coefficient estimate and the covariance between the income and YOUTH coefficients are such that, when evaluated at the sample mean of YOUTH, the elasticity of the occupant fatality rate with respect to income is no longer significant.
} 
demographic trend alone could account for nearly $30 \%$ of the decline in occupant fatalities per VKT during this period.

The positive relationship between YOUTH and fatalities per VKT finding agrees with results in the literature, including Peltzman (1975), Noland (2003a) and Page (2001). ${ }^{20}$ However, the importance of demographics is more pronounced here than in most within-country studies that are limited to shorter periods of analysis. Using countylevel data for 1970 and 1980, Keeler (1994), for example, finds increases in the young population to increase traffic fatalities but the result is not significant.

An interesting implication of Table 7 is that, because the coefficient on the YOUTH-income interaction term is negative in all specifications, the importance of young drivers diminishes as incomes increase. The elasticity with respect to YOUTH exceeds 2.0 (0.50) for per capita incomes less than $\$ 5,900$ (1996 international dollars $)^{21}$ but falls to 0.08 (0.26) once per capita income reaches $\$ 25,000 .^{22}$ This result could reflect changes in young people's attitudes toward risk or an increase in education of young drivers with increases in economic prosperity.

In contrast to the effects of YOUTH, the percentage of driving age population aged 65 and over (ELDERLY) has a small, positive but insignificant effect on occupant

\footnotetext{
${ }^{20}$ Peltzman (1975) found the elasticity with respect to the vehicle occupant death rate to be 0.594 (t-stat $=$ 7.002 ) in the U.S. over 1947-65, although he included motorcyclist deaths with non-occupants. Page (2001) estimates the elasticity with respect to total fatalities to be 0.83 (0.11) for OECD countries over 1980-94. Noland (2003a) finds the elasticity ranges from $0.49(\mathrm{t}-\mathrm{stat}=2.17)$ to $1.11(\mathrm{t}$-stat $=6.58)$ over 1970-96, depending on what other controls are included in the model.

${ }^{21}$ This is the approximate per capita income (1996 international dollars) of Portugal and Hungary in the late 1960 s to early 1970 s and Turkey in the early 1990 s.

${ }^{22}$ This is approximately the income of the U.S. around 1990 and Denmark and Norway in the late 1990s.
} 
fatalities per $\mathrm{VKT}^{23}{ }^{23}$ Likewise, the percentage of population living in urban areas

(URBAN) has an insignificant effect on the occupant fatality rate. ${ }^{24}$

Motorization. Increases in the size of the motor vehicle fleet (VEH) increase occupant fatalities per VKT, as the formal model suggests, but this result is significant only in some specifications. Moreover, the negative coefficient on the vehicle-time trend interaction $(\ln (\mathrm{VEH}) * \mathrm{t})$ indicates that the effect diminishes over time. For example, in the Base Model the elasticity of occupant fatalities with respect to the size of the vehicle fleet decreases from 0.38 in the mid-1960s to approximately zero by the mid-1990s. This result is consistent with newer, safer vehicles providing additional protection to vehicle occupants.

The percentage of motorized two-wheelers in the vehicle stock (2WHEELERS) has no effect on the occupant fatality rate (Model 7). This is somewhat surprising given the increased vulnerability of motorcycle accident victims to bodily injury.

The results suggest that the occupant fatality rate increases with a country's rate of motorization. In the Base Model in Table 7, the coefficient on the annual growth rate of the motor vehicle fleet (VEHGROWTH) is found to be $0.587(0.278)$. Since VEHGROWTH enters the model in linear form, the magnitude of this effect is not large. Considering that VEHGROWTH fell from approximately 0.06 to 0.02 in several

\footnotetext{
${ }^{23}$ Few other studies have examined the effect of this age cohort on occupant and pedestrian fatalities separately. Noland (2003a) did find an increase in the percentage of population aged 65 and over to be associated with an increase in total traffic deaths but the result loses significance as he adds other variables (medical treatment proxies) to the model. Using U.S. county level data for 1970 and 1980, Keeler (1994) also found a positive but insignificant effect of elderly on the total traffic deaths per capita.

${ }^{24}$ This result differs somewhat from Noland's (2003a) finding that increasing population reduces total fatalities. Noland attributes negative coefficient on total population to increasing congestion.
} 
countries over the sample period, ${ }^{25}$ the results imply that decreases in the rate of motorization contributed to less than a 3 percent decline in occupant fatalities/VKT. ${ }^{26}$

Road Infrastructure. Road building is found to increase road safety, as suggested by the formal models, but trends in road conditions (as proxied by the road length-time trend interaction $(\ln (\mathrm{RD}) * \mathrm{t}))$ offset this effect. The results in the Base Model indicate that the elasticity with respect to the road network decreases in magnitude from about $0.39(0.16)$ in the early 1960 s to approximately zero $(0.02(0.13))$ by the mid-1990s. ${ }^{27}$

Since total route length does not decrease over time, increases in the road-time interaction $(\ln (\mathrm{RD}) * \mathrm{t})$ could reflect an aging or deterioration of the existing road network, if repairs are not kept up. Alternatively, if the building of new roads is positively correlated with road maintenance and improvements (lane widening, etc.) on existing routes, then the positive coefficient on the road length-time trend interaction may suggest that trends in road improvements have led to an increase in risk taking behavior on the part of drivers in response to presumably safer roads conditions_-driving faster on straighter, wider roads (or highways). ${ }^{28}$ This result is consistent with Noland's (2003b) finding that road infrastructure improvements - additional lane-miles, lane widening and changes in geometric design - may even lead to increases in traffic fatalities. ${ }^{29}$ Since the interpretation of the route length-time trend interaction is not clear, measuring the net

\footnotetext{
${ }^{25}$ For example, the annual growth rate of the vehicle fleet fell from $5.9 \%$ in 1965 to $1.9 \%$ in 2002 in Austria, from $6.0 \%$ to $1.1 \%$ in Denmark, and from $5.0 \%$ to $2.0 \%$ in the United States.

${ }^{26}$ Appendix B of Kopits (2004) shows the sensitivity analysis of the Base Model results with respect to the specification of this variable and the countries included in the sample. In general, the coefficient increases in magnitude as more years are included in the average growth rate and if South Korea is dropped from the sample. All other coefficient estimates remain stable across specifications. In the interest of maintaining the largest sample size possible, we continue to use VEHGROWTH in our estimation.

${ }^{27}$ The magnitude of the coefficient on total route length (and, hence, the overall elasticity) approximately doubles in magnitude when LIVER is included in the estimation (Model 3 in Table 7).

${ }^{28}$ Mahalel and Szternfeld (1986) hypothesize that drivers may also feel safer on wider roads and reduce cautionary behavior.

${ }^{29}$ Similarly, using monthly data for 18 counties in Norway, Fridstrom and Ingebrigsten (1991) also found improvements to the national road network had no beneficial effect on safety rates.
} 
effect of trends in road conditions on traffic deaths per VKT requires more detailed data on road maintenance.

Alcohol. Alcohol consumption (ALCOHOL) has the expected positive sign (increasing fatalities per VKT) but is small in magnitude and statistically insignificant (Model 4 in Table 7). The imprecision of this coefficient could be a result of measurement error since per capita alcohol consumption is such a crude measure of the amount of drunk driving. Replacing ALCOHOL with data on alcohol-attributable death rates, such as the number of deaths due to cirrhosis of the liver (LIVER), may provide a better measure of excessive alcohol consumption. LIVER indeed has a positive and significant effect on occupant deaths per VKT (Model 3). ${ }^{30}$ This reflects an increase in the probability of a drunk driver being unable to avoid an imminent accident ( $\mathrm{q}$ in equation (11)).

Trends in liver cirrhosis death rates have varied somewhat across high-income countries over the 1970-2000 period. The death rate decreased substantially in the U.S. and many European countries (by 30 to $50 \%$, and by as much as 57\% in France), although some countries (e.g., Finland, Hungary, and the United Kingdom) have experienced increases during much of this time. Given the LIVER coefficient estimate of $0.10(0.05)$ in Table 7 , this suggests that reductions in alcohol use contributed to less than a $6 \%$ decline in the occupant fatality rate in most high-income countries over these decades.

Medical Treatment Indicators. Increases in the availability of medical services (as proxied by the number of physicians per capita (PHYSICIANS)) have a significant,

\footnotetext{
${ }^{30}$ The coefficient remains significant and of the same magnitude when other controls (e.g., the availability of medical services) are added to the model (Kopits, 2004).
} 
negative effect on the occupant fatality rate. ${ }^{31}$ Overall, this is consistent with Noland's (2003a) finding that more physicians per capita led to reductions in total fatalities in a similar set of countries during 1970-1996, although he did not control for the length of the road network. ${ }^{32}$

To summarize the results from Table 7, decreases in the percentage of young drivers are significant in explaining the decline in occupant fatality rates over the past few decades. Trends in road building are associated with declines in occupant fatalities per VKT, especially in the early years of the sample period. Growth in the size of vehicle fleets, on the other hand, increased occupant fatality rates, but this effect was gradually offset by the improvements in vehicle safety features over time. Finally, reductions in alcohol abuse and increased availability of medical care appear significant in reducing occupant deaths per VKT.

\section{3.b. Factors Affecting the Pedestrian Fatality Rate}

Many of the factors that are associated with occupant fatality risk are also significant in explaining the decline in pedestrian fatalities per VKT, but there are important differences. Reductions in the percent of drivers between 15 and 24 reduced pedestrian fatalities per VKT, and the magnitude of this effect is similar to the impact of the variable in the occupant equations. In contrast to the occupant equations, however,

\footnotetext{
${ }^{31}$ The significance of the effect diminishes when other controls (e.g., LIVER) are added to the model that reduce the sample size (Kopits, 2004). In part, the insignificance of the PHYSICIANS coefficient in the other specifications could be due to multicollinearity between PHYSICIANS and RD and VEH. (As shown in Table 6 , the correlation coefficients of $\ln$ (PHYSICIANS) with $\ln (\mathrm{RD})$ and $\ln (\mathrm{VEH})$ are 0.9063 and 0.9558 , respectively.)

${ }^{32}$ Kopits (2004) also explored the effects of an alternate measure of the quality of emergency medical care: the heart attack survival rate. Since it is less correlated with the other explanatory variables, the precision of coefficient estimates should be less affected by multicollinearity issues than with PHYSICIANS. However, since panel lengths and overall sample size shrink so dramatically with the inclusion of this variable, we hesitate to focus on the results from this specification here.
} 
the percent of the population over 65 significantly increases pedestrian fatality risk, as does the percent of population in urban areas. Increases in the size of the vehicle fleet, which proxy reduced pedestrian exposure, reduce pedestrian fatality risk, whereas VEH initially increases occupant fatality risk. It is also the case that much of the reduction in pedestrian fatalities remains unexplained, as evidence by the large, significant negative coefficients on the time trends. These results are discussed in detail below.

Demographic Trends. An increase in the percentage of driving age population between 15 and 24 (YOUTH) has a positive effect on the pedestrian fatality rate, with an elasticity (evaluated at the sample mean of per capita income) ranging from $0.58(0.33)$ to 0.82 (0.33). These results imply that, as in the case of vehicle occupants, this demographic trend could account for over a $20 \%$ decline in pedestrian fatalities per VKT over the sample period. (Likewise, the coefficient on the YOUTH-income interaction term is negative in all specifications in Table 8 although it is significant only when LIVER is included in the model.) The positive relationship between YOUTH and the non-occupant fatality rate agrees with Peltzman (1975), although he included motorcyclist deaths with non-occupants.

Interestingly, the percentage of driving age population aged 65 and over (ELDERLY) is found to have a much larger positive effect on pedestrian fatalities per VKT than on the occupant fatality rate. Given the elasticity estimate of $0.71(0.26)$ in the Base Model and the fact that ELDERLY increased by $21 \%$ on average over 1970-2000 (from $14.46 \%$ to $18.22 \%$ ) for the countries in the sample, our results suggest that population aging trends have dampened the improvements in pedestrian road safety by almost $15 \%$ over the past three decades. 
The cause of the differential effect of ELDERLY across the two equations is unclear. If elderly people are more likely to walk than to be drivers then the significant effect in the pedestrian equation could simply be a result of an increase in the total number of pedestrians. ${ }^{33}$ On the other hand, it could reflect an increase in accidents caused by elderly drivers ${ }^{34}$ or lower pedestrian crash survival rates of elderly accident victims (in which case the occupant fatalities/VKT remain unchanged because of the protection offered by vehicle safety devices such as seatbelt and airbags). Clarifying the causes of the ELDERLY coefficient remains a topic for future research.

Pedestrian fatalities per VKT do not increase with total population. However, the elasticity with respect to URBAN is near one, presumably reflecting an increase in total pedestrian activity. Given that URBAN increased from 64 to 74 percent on average for the countries in the sample, the results suggest that increases in the urban population have dampened improvements in the pedestrian fatality rate by over $15 \%$ over $1970-2000 .^{35}$

Motorization. Increases in the size of the motor vehicle fleet (VEH) reduce pedestrian fatalities per VKT, as the formal model suggests, although the effect is generally insignificant in the early years of the sample period. The negative coefficient on the vehicle-time trend interaction $(\operatorname{lnVEH} * t)$, however, indicates that the effect

\footnotetext{
${ }^{33}$ Alternatively, pedestrian-motor vehicle accident risk could be higher for older pedestrians (Koepsell et al., 2002).

${ }^{34}$ If the accidents are occurring at lower speeds then vehicle occupant fatalities per accident may not increase but pedestrian deaths per accident will. However, the findings here do not seem to be a result of the hypothesis that slower speeds by elderly drivers could increase the variance in driving speed, thereby increasing fatality rates (Lave, 1985), since that should have caused occupant deaths per VKT to increase as well.

${ }^{35}$ Although this is a seemingly large impact, note that the result is not robust across all specifications in Tables 8 and B.2. The magnitude of the URBAN coefficient is consistently near one but becomes statistically insignificant with the inclusion of alcohol control variables and when two-wheeler deaths are added to the dependent variable.
} 
increases over time; by 1995, the elasticity with respect to vehicles increases in magnitude to $-0.58(0.20)$ (Model 1).

The pedestrian fatality rate also increases with a country's rate of motorization (VEHGROWTH), and at a somewhat faster rate than in the occupant equation. Even with a coefficient estimate as high as $1.08(0.34)$ (Model 3) the magnitude of this effect is not large; decreases in the rate of motorization contributed to approximately 4 percent decrease in pedestrian fatalities per VKT over the sample period. The pedestrian fatality rate is unaffected by changes in the percentage of motorized two-wheelers in the vehicle stock (2WHEELERS) (Model 5).

Road Infrastructure. The beneficial effect of road building is slightly larger in the pedestrian equation than in the occupant equation, perhaps because larger road networks include more motorways that are separated from foot traffic. The positive coefficient on the road length-time trend interaction $(\ln (\mathrm{RD}) * t)$, however, is of nearly the same magnitude as in the occupant equation. This suggests that road building has a large negative effect (with an elasticity of $-0.472(0.262)$ in the Base Model) in the early $1960 \mathrm{~s}$, but by the mid-90s, due to the effect of RD*t, has a coefficient close to zero $(-0.170$ (0.209) in the Base Model). ${ }^{36}$

Alcohol. Per adult alcohol consumption (ALCOHOL) is insignificant in explaining pedestrian deaths per VKT. Alcohol use, as proxied by the death rate due to cirrhosis of the liver (LIVER), is, however, significant, and the magnitude of the effect is

\footnotetext{
${ }^{36}$ As with vehicle occupants, the magnitude of the coefficient on total route length (and, hence, the overall elasticity) approximately doubles in magnitude when LIVER is included in the estimation (Model 5 in Table 8).
} 
twice as large as in the case of vehicle occupants. ${ }^{37}$ This likely reflects not only an increase in the probability of a drunk driver being unable to avoid an imminent accident (q), but also risky behavior by pedestrians under the influence of alcohol (thereby increasing $\mathrm{e}^{\prime}$ in equation $\left(10^{\prime}\right)$ ). Long-term trends in the liver cirrhosis death rate and the LIVER coefficient estimate of $0.22(0.07)$ in Table 8 suggests that changes in alcohol use contributed to less than a $10 \%$ decline in pedestrian deaths/VKT in most high-income countries over 1970-2000.

Medical Treatment Indicators. Increases in the availability of medical services (as proxied by the number of physicians per capita (PHYSICIANS)) have a negative effect on the pedestrian fatality rate but is statistically insignificant. In part, the insignificance of the PHYSICIANS coefficient could be due to multicollinearity issues although it is also not surprising that an increase in medical services has a larger impact on the occupant fatality rate than on pedestrian fatalities. One could assume that the likelihood of death is higher for unprotected road users such as pedestrians and bicyclists than vehicle occupants, regardless of how quickly accident victims are rushed to the hospital or the quality of available medical care.

To summarize the results from Table 8 , decreases in the percentage of young drivers and trends in road building have contributed to improvements in pedestrian safety over the past few decades, and to a similar degree as in the case of vehicle occupants. Growth in the size of vehicle fleets and improvements in vehicle safety features also contributed to the decline in the pedestrian fatality rate, especially in the later years of the sample period. Reductions in alcohol abuse have a larger impact on pedestrians than

\footnotetext{
${ }^{37}$ As in the case of vehicle occupants, the LIVER coefficient is robust to the inclusion of other variables (Kopits, 2004).
} 
vehicle occupants. However, the results also suggest that improvements in pedestrian safety were significantly dampened by urban and elderly population growth over the sample period.

\section{Conclusions}

In order to examine fatalities per distance traveled we must use data from countries with reliable information on VKTs. This limits our study to high-income countries. We believe, however, that the experience of the IRTAD countries over the period 1963-2002 is relevant to the current situation faced by developing countries. The levels of per capita income of the poorest IRTAD countries in 1963 (e.g., Korea, Greece, Ireland and Portugal) were the same as (sometimes below) the income levels of many low- to middle-income countries today. Moreover, the pattern of traffic fatalities in many IRTAD countries at the beginning of our panel was similar to those recently observed in developing countries: in 1970, the ratio of pedestrian to total traffic fatalities exceeded $40 \%$ in nine IRTAD countries. We therefore believe that our findings have implications for developing countries today.

We find that the decline in the road death rate (fatalities/population) with income at high income levels (Kopits and Cropper 2005) is dominated by a decline in the pedestrian death rate. Both pedestrian fatalities per VKT and per capita have steadily declined with growth in per capita income in the IRTAD countries, at least over the range of incomes one can expect in low- and middle-income developing countries over the next 20 years. Our more detailed models fail to explain exactly why this decline occurred; 
however, increased motorization and a reduction in the proportion of young drivers in the population clearly played a role.

Our results suggest, however, that reductions in occupant fatalities will not automatically accompany increases in income. Neither occupant fatalities per VKT nor occupant fatalities per capita show a significant decline with income in the IRTAD countries. What does explain declines in occupant fatalities per VKT are reductions in alcohol abuse and improved medical services, and a reduction in the young driving age population. Reductions in alcohol abuse and improved medical services are clearly the result of explicit resource allocation decisions. The importance of demographic factors suggests that in countries where young persons (between 15 and 24 years of age) comprise an increasing share of the driving population, adopting policies to improve young driver education and reduce speeds will be crucial. The importance of young drivers in road fatalities diminished in industrialized countries as incomes increased, reflecting either increased risk aversion or more widespread driver education with increases in economic prosperity. However, the increased risk to both vehicle occupants and pedestrians posed by young road users more than offsets this beneficial effect of income growth, suggesting that interventions aimed at young drivers are still needed. 


\section{References}

Asch, Peter, and David T. Levy. 1987. Does the Minimum Drinking Age Affect Traffic Fatalities? Journal of Policy Analysis and Management 6(2): 80-92.

Baltagi, B.H. 1995. Econometric Analysis of Panel Data. John Wiley and Sons.

Branas, C.C., and M.M. Knudson. 2001. Helmet Laws and Motorcycle Rider Death Rates. Accident Analysis and Prevention 33(5): 641-8.

Cohen, Alma, and Liran Einav. 2003. The Effects of Mandatory Seat Belt Laws on Driving Behavior and Traffic Fatalities. The Review of Economics and Statistics 85(4): 828-843.

Dee, Thomas S. 1999. State Alcohol Policies, Teen Drinking, and Traffic Fatalities. Journal of Public Economics 72(2):289-315.

Dee, Thomas S., and William N. Evans. 2001. Behavioral Policies and Teen Traffic Safety. AEA Papers and Proceedings 91-96.

Edlin, Aaron S. 1999. Per Mile Premiums for Auto Insurance. Working Paper 6934, National Bureau of Economic Research.

Evans, Leonard. 1986. The Effectiveness of Safety Belts in Preventing Fatalities. Accident Analysis and Prevention 18(3): 229-41.

Evans, W.N., and J.D. Graham. 1991. Risk Reduction or Risk Compensation? The Case of Mandatory Safety-Belt Use Laws. Journal of Risk and Uncertainty 4(1): 61-73.

Fridstrom, Lasse, and Siv Ingebrigsten. 1991. An Aggregate Model Based on Pooled, Regional Time-Series Data. Accident Analysis and Prevention 23: 363-378.

Garbacz, C. 1989. Traffic Fatalities in Taiwan. Journal of Transport Economics and Policy 23(3): 317-27.

Garbacz, C. 1990. Estimating Seat Belt Effectiveness with Seat Belt Data from the Centers for Disease Control. Economic Letters 34: 83-88.

Garbacz, C. 1991. Impact of the New Zealand Seat Belt Law. Economic Inquiry 29: 310-16.

Garbacz, C. 1992. More Evidence on the Effectiveness of Seat Belt Laws. Applied Economics 24: 313-315.

Heston, Alan, Robert Summers, and Bettina Aten. 2002. Penn World Table Version 6.1, Center for International Comparisons at the University of Pennsylvania (CICUP), October. 
International Road Federation. (Various years). I.R.F. World Road Statistics. International Road Federation, Geneva, Switzerland.

International Road Traffic Accident Database (IRTAD). Federal Highway Research Institute (BASt)/OECD Road Transport Research Programme, Paris, France.

Keeler, Theodore E. 1994. Highway Safety, Economic Behavior and Driving Environment. American Economic Review 84(3): 684-693.

Koepsell, Thomas, et al. 2002. Crosswalk Markings and the Risk of Pedestrian-Motor Vehicle Collisions in Older Pedestrians. Journal of the American Medical Association 288(17): 2136-43.

Kopits, Elizabeth, and Maureen Cropper. 2005. Traffic Fatalities and Economic Growth. Accident Analysis and Prevention 37(1): 169-78.

Kopits, Elizabeth. 2004. Traffic Fatalities and Economic Growth. PhD Dissertation, University of Maryland-College Park.

Lave, C. 1985. Speeding, Coordination, and the 55 MPH Speed Limit. American Economic Review 75: 1159-64.

Lee, J., and F. Mannering. 2002. Impact of roadside features on the frequency and severity of run-off roadway accidents: an empirical analysis. Accident Analysis and Prevention 34(2): 149-161.

Liang, Kung-Yee, and Scott Zeger. 1986. Longitudinal Data Analysis Using Generalized Linear Models. Biometrika 73(1):13-22.

Lindgren, Bjorn, and Charles Stuart. 1980. The Effects of Traffic Safety Regulation in Sweden. The Journal of Political Economy 88(2): 412-27.

Mahalel, David, and Zvi Szternfeld. 1986. Safety Improvements and Driver Perception. Accident Analysis and Prevention 18(1): 37-42.

McCornac, Dennis C. 1993. The Efficacy of Government Safety Policies on Trafficrelated Fatalities: Empirical Estimates from Japan. Applied Economics 25: 409-412.

Noland, Robert. 2003a. Medical treatment and traffic fatality reductions in industrialized countries. Accident Analysis and Prevention 35: 877-83.

Noland, Robert. 2003b. Traffic fatalities and injuries: the effect of changes in infrastructure and other trends. Accident Analysis and Prevention 35(4): 599-611.

Nunziata, L. 2002. xtdw.ado: a Stata command for Durbin Watson statistic in fixed effects panel data models. Available to download from: http://www.nuff.ox.ac.uk/users/nunziata/publications.htm. 
Organization for Economic Cooperation and Development (OECD). Annual National Accounts for OECD Member Countries. Comparative tables available from OECD Statistical Database:

http://www.oecd.org/document/28/0,2340,en_2825_495684_2750044_1_1_1_1,00.ht $\underline{\mathrm{ml}}$.

Organization for Economic Cooperation and Development (OECD). Health Data 2003. http://www.oecd.org/document/30/0,2340,en_2649 34631_12968734_1_1_1_1,00.ht $\underline{\mathrm{ml}}$

Organization for Economic Cooperation and Development (OECD). (Various years). OECD Energy Statistics.

Page, Yves. 2001. A Statistical Model to Compare Road Mortality in OECD Countries. Accident Analysis and Prevention 33: 371-85.

Peden, M., et al., Eds. 2004. World Report on Road Traffic Injury Prevention. Geneva, Switzerland: World Health Organization.

Peltzman, Sam. 1975. The Effects of Automobile Safety Regulation. Journal of Political Economy 83(4): 677-726.

Risa, Alf Erling. 1994. Adverse Incentives from Improved Technology: Traffic Safety Regulation in Norway. Southern Economic Journal 60(4): 844-57.

Ruhm, Christopher J. 1996. Alcohol Policies and Highway Vehicle Fatalities. Journal of Health Economics 15:435-454.

Sass, T.R., and P.R. Zimmerman. 2000. Motorcycle Helmet Laws and Motorcyclist Fatalities. Journal of Regulatory Economics 18(3): 195-215.

Scuffman, P.A. 2003. Economic Factors and Traffic Crashes in New Zealand. Applied Economics 35(2): 179-188.

Scuffman, P.A., and J.D. Langley. 2002. A Model of Traffic Crashes in New Zealand. Accident Analysis and Prevention 34(5): 673-87.

Sen, Anindya. 2001. An Empirical Test of the Offset Hypothesis. Journal of Law and Economics 44: 481-510.

United Nations. World Population Prospects: The 2002 Revision Population Database. http://esa.un.org/unpp/.

U.S. Census Bureau. International Data Base (IDB). http://www.census.gov/ipc/www/idbsprd.html.

Wooldridge, Jeffrey. 2003. Cluster-Sample Methods in Applied Econometrics. Working Paper. Michigan State University. 
World Bank. World Development Indicators 2004.

http://www.worldbank.org/data/wdi2004/index.htm.

World Drink Trends. 2000. World Drink Trends 2000: International Beverage Consumption and Production Trends. Henley-on-Thames, Oxfordshire, U.K.: NTC Publications Ltd.

Zlatoper, T.J. 1984. Regression-Analysis of Time-Series Data on Motor Vehicle Deaths in the United States. Journal of Transport Economics and Policy 18(3): 263-274. 
Table 1. Traffic Fatality Trends in Industrialized Countries, 1970-99

(\% Change, unless otherwise indicated)

\begin{tabular}{|c|c|c|c|c|c|c|c|}
\hline Country & $\begin{array}{c}\text { Pedestrian } \\
\text { Deaths }\end{array}$ & $\begin{array}{l}\text { Occupant } \\
\text { Deaths }\end{array}$ & $\begin{array}{c}\text { Pedestrian } \\
\text { Deaths, } \\
1999 \\
\text { (\% of total) }\end{array}$ & $\begin{array}{l}\text { Total } \\
\text { VKT }\end{array}$ & $\begin{array}{c}\text { Pedestrian } \\
\text { Deaths/ } \\
\text { VKT }\end{array}$ & $\begin{array}{l}\text { Occupant } \\
\text { Deaths/ } \\
\text { VKT }\end{array}$ & $\begin{array}{c}\text { Total } \\
\text { Deaths/ } \\
\text { VKT }\end{array}$ \\
\hline Australia & $-54^{\mathrm{b}}$ & $-44^{\mathrm{b}}$ & 19 & +125 & $-65^{b}$ & $-57^{b}$ & -79 \\
\hline Austria & -76 & -47 & 23 & +207 & -92 & -83 & -86 \\
\hline Belgium & $-74^{\mathrm{a}}$ & $-40^{\mathrm{a}}$ & 20 & +204 & $-90^{a}$ & $-76^{a}$ & -85 \\
\hline Canada & -63 & -34 & 16 & $+127^{\mathrm{d}}$ & $-58^{n}$ & $-29^{n}$ & $-37^{n}$ \\
\hline Czech Republic & $-26^{b}$ & $+60^{b}$ & 33 & $+80^{\mathrm{b}}$ & $-59^{b}$ & $-12^{b}$ & $-36^{b}$ \\
\hline Denmark & -71 & -49 & 27 & +94 & -85 & -74 & -78 \\
\hline Finland & -73 & -48 & 30 & +177 & -90 & -81 & -85 \\
\hline France & -71 & -40 & 15 & +187 & -90 & -79 & -82 \\
\hline Germany & -82 & -52 & 21 & +168 & -93 & -82 & -87 \\
\hline Greece & 0 & +150 & 20 & $+585^{\mathrm{e}}$ & $-83^{\mathrm{e}}$ & $-65^{\mathrm{e}}$ & $-71^{\mathrm{e}}$ \\
\hline Hungary & -20 & -19 & 46 & $+238^{f}$ & $-75^{f}$ & $-74^{f}$ & $-75^{f}$ \\
\hline Iceland & $-44^{\mathrm{b}}$ & $0^{\mathrm{b}}$ & 24 & $+159^{g}$ & $-68^{b}$ & $-42^{b}$ & $-51^{b}$ \\
\hline Ireland & -62 & +16 & 26 & $+141^{\mathrm{h}}$ & $-74^{\mathrm{h}}$ & $-57^{\mathrm{h}}$ & $-64^{h}$ \\
\hline Italy & -70 & -22 & 19 & $+132^{i}$ & $-82^{i}$ & $-60^{i}$ & $-68^{i}$ \\
\hline Japan & -58 & -48 & 42 & +238 & -87 & -85 & -86 \\
\hline Luxembourg & -95 & -37 & 3 & $+116^{j}$ & $-85^{j}$ & $-66^{j}$ & $-69^{j}$ \\
\hline Netherlands & -73 & -62 & 28 & +127 & -88 & -83 & -85 \\
\hline New Zealand & -43 & -17 & 14 & +199 & -81 & -72 & -74 \\
\hline Norway & -79 & -24 & 16 & +178 & -92 & -73 & -80 \\
\hline Poland & $-2^{b}$ & $+28^{b}$ & 47 & +1317 & $-73^{b}$ & $-64^{b}$ & -86 \\
\hline Portugal & -42 & +79 & 22 & $+175^{\mathrm{k}}$ & $-95^{\mathrm{k}}$ & $-80^{k}$ & $-89^{k}$ \\
\hline South Korea & $-40^{c}$ & $+7^{\mathrm{c}}$ & 41 & $+594^{1}$ & -73 & $-48^{\circ}$ & $-62^{\circ}$ \\
\hline Spain & -43 & +29 & 18 & +448 & -90 & -77 & -81 \\
\hline Sweden & -71 & -48 & 23 & +88 & -85 & -72 & -76 \\
\hline Switzerland & -75 & -59 & 27 & +88 & -87 & -78 & -81 \\
\hline Turkey & $-59^{c}$ & $-18^{\mathrm{c}}$ & 22 & +716 & $-82^{c}$ & $-63^{c}$ & $-70^{c}$ \\
\hline \multicolumn{8}{|l|}{ United } \\
\hline Kingdom & -69 & -43 & 30 & $+130^{\mathrm{m}}$ & $-86^{\mathrm{m}}$ & $-75^{\mathrm{m}}$ & $-80^{\mathrm{m}}$ \\
\hline United States & -41 & -16 & 14 & +144 & -76 & -66 & -68 \\
\hline
\end{tabular}


Table 2. Pedestrian and Occupant Fatalities/VKT as a function of income and time ${ }^{\mathrm{a}}$

\begin{tabular}{|c|c|c|c|c|c|c|c|c|}
\hline & \multicolumn{3}{|c|}{ In(Pedestrian Fatalities/VKT) } & \multirow{2}{*}{$\begin{array}{c}\begin{array}{c}\text { In(Pedestrian } \\
\text { Fatalities/ } \\
\text { Population) }\end{array} \\
4\end{array}$} & \multicolumn{3}{|c|}{ In(Occupant Fatalities/VKT) } & \multirow{2}{*}{$\begin{array}{c}\begin{array}{c}\text { In(Occupant } \\
\text { Fatalities/ } \\
\text { Population) }\end{array} \\
4\end{array}$} \\
\hline & 1 & 2 & 3 & & 1 & 2 & 3 & \\
\hline $\ln Y$ & $\begin{array}{c}-0.643 * * * \\
(0.146)\end{array}$ & $\begin{array}{c}-3.494 \\
(3.633)\end{array}$ & & & $\begin{array}{c}-0.237 \\
(0.188)\end{array}$ & $\begin{array}{c}-4.503 * * \\
(1.952)\end{array}$ & & \\
\hline$(\ln Y)^{2}$ & & $\begin{array}{c}0.148 \\
(0.189) \\
\end{array}$ & & & & $\begin{array}{c}0.222 * * \\
(0.100) \\
\end{array}$ & & \\
\hline $\begin{array}{l}\ln Y \text { for: } \\
\$ 4,552-13,165\end{array}$ & & & $\begin{array}{c}-0.706^{* * *} \\
(0.270)\end{array}$ & $\begin{array}{c}0.653 * * * \\
(0.187)\end{array}$ & & & $\begin{array}{l}-0.328 \\
(0.233) \\
\end{array}$ & $\begin{array}{c}1.030 * * * \\
(0.293)\end{array}$ \\
\hline$\$ 13,165-16,565$ & & & $\begin{array}{c}-1.073 * * * \\
(0.339) \\
\end{array}$ & $\begin{array}{c}-0.680 * \\
(0.370) \\
\end{array}$ & & & $\begin{array}{c}-0.675^{* *} \\
(0.293) \\
\end{array}$ & $\begin{array}{c}-0.283 \\
(0.401) \\
\end{array}$ \\
\hline$\$ 16,565-20,700$ & & & $\begin{array}{c}-0.776^{* *} \\
(0.390) \\
\end{array}$ & $\begin{array}{c}-0.847^{*} \\
(0.488) \\
\end{array}$ & & & $\begin{array}{l}-0.210 \\
(0.364) \\
\end{array}$ & $\begin{array}{c}-0.281 \\
(0.539) \\
\end{array}$ \\
\hline$\$ 20,700-44,227$ & & & $\begin{array}{l}-0.180 \\
(0.339)\end{array}$ & $\begin{array}{c}-0.488 * * \\
(0.239)\end{array}$ & & & $\begin{array}{c}0.198 \\
(0.195) \\
\end{array}$ & $\begin{array}{l}-0.109 \\
(0.268)\end{array}$ \\
\hline Common $\mathrm{T}$ & $\begin{array}{c}0.060 * * * \\
(0.004) \\
\end{array}$ & $\begin{array}{c}-0.060 * * * \\
(0.004)\end{array}$ & $\begin{array}{c}-0.059 * * * \\
(0.005)\end{array}$ & $\begin{array}{c}-0.033 * * * \\
(0.006) \\
\end{array}$ & $\begin{array}{c}0.044 * * * \\
(0.004)\end{array}$ & $\begin{array}{c}-0.044 * * * \\
(0.004)\end{array}$ & $\begin{array}{c}-0.043 * * * \\
(0.005) \\
\end{array}$ & $\begin{array}{c}-0.017 * * \\
(0.008)\end{array}$ \\
\hline $\begin{array}{l}\text { Constant } \\
\text { (Austria) }\end{array}$ & $\begin{array}{c}3.056 * * \\
(1.360)\end{array}$ & $\begin{array}{c}16.748 \\
(17.451) \\
\end{array}$ & $\begin{array}{c}3.692 \\
(2.533) \\
\end{array}$ & $\begin{array}{c}-15.253 * * * \\
(1.705)\end{array}$ & $\begin{array}{c}-0.267 \\
(1.741)\end{array}$ & $\begin{array}{c}20.222 * * \\
(9.591)\end{array}$ & $\begin{array}{c}0.642 \\
(2.158) \\
\end{array}$ & $\begin{array}{c}-18.387 * * * \\
(2.683)\end{array}$ \\
\hline $\begin{array}{l}\text { Turning Point } \\
\text { (1996 Int'1\$): }\end{array}$ & & $\$ 129,500$ & & & & $\$ 25,384$ & & \\
\hline Adjusted $\mathrm{R}^{2}$ : & 0.9543 & 0.9547 & 0.9560 & 0.8585 & 0.9468 & 0.9485 & 0.9502 & 0.8204 \\
\hline Countries & 32 & 32 & 32 & 32 & 32 & 32 & 32 & 32 \\
\hline Observations & 830 & 830 & 830 & 830 & 830 & 830 & 830 & 830 \\
\hline
\end{tabular}

*** Indicates $1 \%$ level of significance ** Indicates $5 \%$ level of significance

* Indicates $10 \%$ level of significance

${ }^{\mathbf{a}}$ Heteroskedasticity-corrected standard errors, clustered on country to allow for within panel autocorrelation, are given in parentheses.

Country fixed effects were included in all regressions but are not displayed here. 
Table 3. Number of Observations Included in Chapter Three Samples, by Country

\begin{tabular}{|c|c|c|c|c|c|}
\hline Country & $\begin{array}{c}\text { Income-Only } \\
\text { Regressions } \\
\text { (Equations } \\
3.11-3.13 \text { ) } \\
\end{array}$ & Base Sample & $\begin{array}{c}\text { Sample with } \\
\text { Urban } \\
\text { Seatbelt } \\
\text { Usage } \\
\end{array}$ & $\begin{array}{c}\text { Sample with } \\
\text { Rural } \\
\text { Seatbelt } \\
\text { Usage } \\
\end{array}$ & $\begin{array}{c}\text { Sample with } \\
\text { Motorway } \\
\text { Seatbelt } \\
\text { Usage } \\
\end{array}$ \\
\hline Australia & 21 & 12 & & & \\
\hline Austria & 34 & 23 & 22 & 22 & 22 \\
\hline Belgium & 29 & 29 & 5 & 5 & 5 \\
\hline Canada & 40 & 25 & 13 & & \\
\hline Chile & 4 & 4 & & & \\
\hline Czech Republic & 13 & 6 & & & \\
\hline Denmark & 33 & 32 & 2 & 2 & 21 \\
\hline Finland & 34 & 31 & 14 & 10 & 1 \\
\hline France & 34 & 33 & 23 & 31 & 31 \\
\hline Germany* & 33 & 26 & 9 & 17 & 9 \\
\hline Greece & 31 & 16 & & & 1 \\
\hline Hungary & 32 & 25 & 5 & 5 & 4 \\
\hline Iceland & 22 & 21 & & & \\
\hline Ireland & 27 & 19 & 1 & 1 & \\
\hline Israel & 13 & 13 & & & \\
\hline Italy & 30 & 27 & & & \\
\hline Japan & 33 & 33 & 26 & & 26 \\
\hline Korea, Republic & 13 & 13 & 3 & & \\
\hline Luxembourg & 30 & 27 & & & \\
\hline Netherlands & 33 & 31 & 17 & 17 & 17 \\
\hline New Zealand & 33 & 25 & 7 & 7 & \\
\hline Norway & 32 & 32 & 24 & 24 & 5 \\
\hline Poland & 18 & 14 & & & \\
\hline Portugal & 22 & 9 & & & \\
\hline Slovak Republic & 4 & 4 & & & \\
\hline Slovenia & 6 & 6 & 6 & 6 & 6 \\
\hline Spain & 32 & 20 & 4 & 3 & 1 \\
\hline Sweden & 34 & 26 & 9 & 9 & 9 \\
\hline Switzerland & 34 & 34 & 33 & 34 & 33 \\
\hline Turkey & 10 & 8 & & & \\
\hline United Kingdom & 33 & 27 & 20 & 5 & \\
\hline United States & 33 & 29 & 18 & & \\
\hline Countries: & 32 & 32 & 20 & 16 & 15 \\
\hline $\begin{array}{l}\text { Total } \\
\text { Observations: }\end{array}$ & 830 & 680 & 261 & 198 & 191 \\
\hline
\end{tabular}

*East and West Germany were treated as a single country for years prior to unification. 
Table 4. List of Variables

\begin{tabular}{|c|c|}
\hline $\begin{array}{l}\text { Pedestrian } \\
\text { Deaths/VKT }\end{array}$ & Number of pedestrians \& bicyclists killed/Million vehicle km traveled \\
\hline Occupant & \\
\hline Deaths/VKT & Number of vehicle occupants killed ${ }^{\mathrm{a}} /$ Million vehicle $\mathrm{km}$ traveled \\
\hline $\mathrm{Y}$ & Real per capita GDP (1996 international prices) \\
\hline YOUTH & Population aged 15-24/Population ages 15 and over \\
\hline ELDERLY & Population ages 65 and over/Population ages 15 and over \\
\hline $\mathrm{VEH}$ & $\begin{array}{l}\text { Total number of vehicles (including cars, buses, trucks, motorized two- } \\
\text { wheelers) }\end{array}$ \\
\hline VEHGROWTH & $\%$ Change in the vehicle stock (VEH) from the previous year \\
\hline 2WHEELERS & Number of motorized two-wheelers, as \% of total vehicle stock (VEH) \\
\hline $\mathrm{RD}$ & Total route length of the road network $(\mathrm{kms})$ \\
\hline POP & Total midyear population \\
\hline URBAN & $\%$ Population living in urbanized areas \\
\hline ALCOHOL & Total alcohol consumption/Population age $18+$ (liters) \\
\hline LIVER & Deaths due to cirrhosis of the liver/100,000 Persons aged 15 and over \\
\hline PHYSICIANS & Number of licensed physicians/10,000 Persons \\
\hline HEART & $\begin{array}{l}\text { Calculated heart attack survival rate; HEART = Number of hospital } \\
\text { discharges following acute myocardial infarction/(Number of hospital } \\
\text { discharges + Number of deaths due to myocardial infarction) }\end{array}$ \\
\hline $\begin{array}{l}\text { Seatbelt - } \\
\text { URBAN Roads }\end{array}$ & $\%$ of Car drivers wearing seatbelts on urban roads \\
\hline $\begin{array}{l}\text { Seatbelt - } \\
\text { RURAL Roads }\end{array}$ & $\%$ of Car drivers wearing seatbelts on rural roads \\
\hline $\begin{array}{l}\text { Seatbelt - } \\
\text { MOTORWAYS }\end{array}$ & $\%$ of Car drivers wearing seatbelts on motorways \\
\hline
\end{tabular}


Table 5. Descriptive Statistics

\begin{tabular}{lcrrrr}
\hline Variable & $\mathrm{N}$ & \multicolumn{1}{l}{ Mean } & Std. Dev. & Minimum & Maximum \\
\hline Income-Only Sample: & & & & & \\
\hline Total Road Deaths & 830 & 5453.396 & 9309.744 & 10 & 54589 \\
\hline Pedestrian Deaths & 830 & 1474.543 & 2095.169 & 1 & 10243 \\
\hline Vehicle Occupant Deaths & 830 & 3978.849 & 7515.317 & 7 & 44399 \\
\hline $\begin{array}{l}\text { Vehicle-Kilometers Traveled } \\
\text { VKT (millions) }\end{array}$ & 830 & 239875.7 & 606124.6 & 1143 & 4478154 \\
\hline Pedestrian Deaths/VKT & 830 & 0.0150 & 0.0254 & 0.0005 & 0.2867 \\
\hline Occupant Deaths/VKT & 830 & 0.0277 & 0.0289 & 0.0036 & 0.2561 \\
\hline $\begin{array}{l}\text { Real per capita GDP } \\
\text { (1996 int'\$) }\end{array}$ & 830 & 17001.370 & 5672.683 & 4552.19 & 44227.23 \\
\hline Year & 830 & 1986.434 & 9.799 & 1963 & 2002 \\
\hline \multicolumn{1}{c}{ Number of countries: } & 32 & & & & \\
\hline
\end{tabular}

Base Sample (Models 1-3 in Tables 3.X-3.X):

\begin{tabular}{|c|c|c|c|c|c|}
\hline Pedestrian Deaths & 680 & 1534.712 & 2172.096 & 1 & 10243 \\
\hline Vehicle Occupant Deaths & 680 & 4132.106 & 7739.631 & 7 & 44399 \\
\hline VKT (millions) & 680 & 254771.4 & 637936.8 & 1185 & 4478154 \\
\hline Pedestrian Deaths/VKT & 680 & 0.0143 & 0.0270 & 0.0005 & 0.2867 \\
\hline Occupant Deaths/VKT & 680 & 0.0260 & 0.0297 & 0.0036 & 0.2561 \\
\hline $\begin{array}{l}\text { Real per capita GDP } \\
\text { (1996 int'1\$) }\end{array}$ & 680 & 17559.22 & 5522.279 & 4552.19 & 43989.44 \\
\hline YOUTH & 680 & 0.1954 & 0.0326 & 0.1309 & 0.3226 \\
\hline ELDERLY & 680 & 0.1633 & 0.0281 & 0.0642 & 0.2169 \\
\hline VEH & 680 & $1.82 \mathrm{E}+07$ & $3.70 \mathrm{E}+07$ & 88000 & $2.21 \mathrm{E}+08$ \\
\hline $\mathrm{RD}(\mathrm{kms})$ & 680 & 522180 & 1242434 & 4447 & 6354229 \\
\hline VEHGROWTH & 680 & 0.0354 & 0.0359 & -0.1211 & 0.3069 \\
\hline POP & 680 & $3.50 \mathrm{e}+07$ & $5.34 \mathrm{e}+07$ & 227000 & $2.85 \mathrm{e}+08$ \\
\hline URBAN (\%) & 680 & 75.0110 & 12.2654 & 23.9000 & 97.3937 \\
\hline Year & 680 & 1987.246 & 9.150 & 1964 & 2002 \\
\hline Number of countries: & 32 & & & & \\
\hline \multicolumn{6}{|l|}{ Other Variables: } \\
\hline ALCOHOL & 581 & 10.67833 & 3.707288 & .6305346 & 21.66784 \\
\hline Countries (Model 4): & 30 & & & & \\
\hline LIVER & 515 & 19.13813 & 14.78251 & .5025126 & 102.9524 \\
\hline Countries (Model 5): & 30 & & & & \\
\hline PHYSICIANS & 536 & 68.02888 & 122.5449 & .397 & 763.519 \\
\hline Countries (Model 6): & 29 & & & & \\
\hline HEART & 181 & 0.6370562 & 0.0661428 & 0.486651 & 0.8059888 \\
\hline Countries (Model 7): & 23 & & & & \\
\hline 2WHEELERS (\%) & 613 & 12.84394 & 11.20714 & 0.6600004 & 60.61508 \\
\hline Countries (Model 8): & 31 & & & & \\
\hline Seatbelt-URBAN Roads (\%) & 261 & 63.82623 & 23.2948 & 3 & 97 \\
\hline Countries (Model 12): & 20 & & & & \\
\hline Seatbelt- RURAL Roads (\%) & 198 & 74.23889 & 19.41811 & 6 & 97 \\
\hline Countries (Model 13): & 16 & & & & \\
\hline Seatbelt-MOTORWAYS(\%) & 191 & 77.2644 & 21.26288 & 12 & 99 \\
\hline Countries (Model 14): & 15 & & & & \\
\hline
\end{tabular}


Table 6. Correlation Coefficients among Independent Variables

Base Sample (Models 1-3; 680 observations):

\begin{tabular}{|c|c|c|c|c|c|c|c|c|c|c|c|c|}
\hline & $\operatorname{Ln}(\mathrm{Y})$ & Ln(YOUTH) & $\begin{array}{l}\mathrm{Ln}(\mathrm{YOUT} \\
\mathrm{H})^{*} \operatorname{Ln}(\mathrm{Y})\end{array}$ & $\begin{array}{r}\operatorname{Ln}(\mathrm{ELDE} \\
\mathrm{RLY}) \\
\end{array}$ & $\begin{array}{r}\text { VEHGRO } \\
\text { WTH } \\
\end{array}$ & $\mathrm{Ln}(\mathrm{VEH})$ & $\operatorname{Ln}(\mathrm{RD})$ & $\mathrm{Ln}(\mathrm{VEH}) * \mathrm{t}$ & $\operatorname{Ln}(\mathrm{RD}) * \mathrm{t}$ & $\mathrm{t}$ & $\operatorname{Ln}(\mathrm{POP})$ & $\begin{array}{r}\mathrm{Ln}(\mathrm{URB} \\
\mathrm{AN}) \\
\end{array}$ \\
\hline $\operatorname{Ln}(\mathrm{Y})$ & 1 & & & & & & & & & & & \\
\hline Ln(YOUTH) & -0.5508 & 1 & & & & & & & & & & \\
\hline Ln(YOUTH)* & & & & & & & & & & & & \\
\hline $\operatorname{Ln}(\mathrm{Y})$ & -0.7328 & 0.9708 & 1 & & & & & & & & & \\
\hline Ln(ELDERLY) & 0.4066 & -0.7042 & -0.6785 & 1 & & & & & & & & \\
\hline VEHGROWTH & -0.4156 & 0.3561 & 0.3998 & -0.5166 & 1 & & & & & & & \\
\hline $\mathrm{Ln}(\mathrm{VEH})$ & 0.1094 & -0.1013 & -0.1112 & 0.0403 & -0.1142 & 1 & & & & & & \\
\hline $\operatorname{Ln}(\mathrm{RD})$ & 0.0142 & 0.0225 & 0.0165 & -0.0226 & -0.1243 & 0.9191 & 1 & & & & & \\
\hline $\mathrm{Ln}(\mathrm{VEH}) * \mathrm{t}$ & 0.3915 & -0.4944 & -0.5219 & 0.2173 & -0.1742 & 0.2977 & 0.1611 & 1 & & & & \\
\hline $\operatorname{Ln}(\mathrm{RD}) * \mathrm{t}$ & 0.3756 & -0.4717 & -0.4987 & 0.2102 & -0.1927 & 0.326 & 0.2386 & 0.9897 & 1 & & & \\
\hline $\mathrm{T}$ & 0.383 & -0.4775 & -0.5067 & 0.2012 & -0.1506 & 0.0256 & -0.0942 & 0.957 & 0.9367 & 1 & & \\
\hline $\mathrm{Ln}(\mathrm{POP})$ & -0.1371 & 0.0385 & 0.0703 & -0.1106 & 0.0441 & 0.9588 & 0.8973 & 0.2086 & 0.2393 & -0.0583 & 1 & \\
\hline Ln(URBAN) & 0.4493 & -0.1193 & -0.2241 & 0.0914 & -0.2874 & 0.0974 & 0.035 & 0.1622 & 0.1517 & 0.1553 & -0.0082 & 1 \\
\hline
\end{tabular}

Other Variables (Number of observations vary according to model):

\begin{tabular}{|c|c|c|c|c|c|c|c|c|c|c|c|c|}
\hline & $\operatorname{Ln}(Y)$ & Ln(YOUTH) & $\begin{array}{l}\operatorname{Ln}(Y O U T \\
H) * \operatorname{Ln}(Y)\end{array}$ & $\begin{array}{r}\operatorname{Ln}(\text { ELDE } \\
\text { RLY) }\end{array}$ & $\begin{array}{r}\text { VEHGRO } \\
\text { WTH }\end{array}$ & $\operatorname{Ln}(\mathrm{VEH})$ & $\mathrm{Ln}(\mathrm{RD})$ & $\operatorname{Ln}(\mathrm{VEH}) * \mathrm{t}$ & $\operatorname{Ln}(\mathrm{RD}) * \mathrm{t}$ & $\mathrm{t}$ & Ln(POP) & $\begin{array}{r}\operatorname{Ln}(\mathrm{URB} \\
\mathrm{AN}) \\
\end{array}$ \\
\hline Ln(ALCOHOL) & 0.1280 & -0.3337 & -0.2950 & 0.3781 & -0.1669 & 0.1469 & 0.0872 & -0.1737 & -0.1868 & -0.2394 & 0.0719 & -0.1382 \\
\hline Ln(LIVER) & -0.2726 & -0.2568 & -0.1221 & 0.1201 & 0.2290 & 0.2910 & 0.1781 & -0.0335 & -0.0650 & -0.1347 & 0.3488 & -0.3252 \\
\hline Ln(PHYSICIANS) & -0.1032 & -0.0318 & 0.0045 & -0.0514 & -0.0281 & 0.9624 & 0.9095 & 0.3758 & 0.4109 & 0.1158 & 0.9770 & -0.0533 \\
\hline 2WHEELERS & -0.4196 & 0.1029 & 0.2032 & -0.2064 & 0.3093 & 0.1071 & 0.0315 & -0.2795 & -0.3006 & -0.3351 & 0.2398 & -0.2921 \\
\hline $\begin{array}{l}\text { Ln(Seatbelt: } \\
\text { URBAN) }\end{array}$ & 0.2724 & -0.4258 & -0.4309 & 0.4364 & -0.3098 & 0.0441 & 0.0119 & 0.6278 & 0.6144 & 0.6671 & -0.0104 & 0.2844 \\
\hline $\begin{array}{l}\text { Ln(Seatbelt: } \\
\text { RURAL) }\end{array}$ & 0.2327 & -0.3954 & -0.3825 & 0.3056 & -0.3023 & 0.0897 & 0.0678 & 0.6437 & 0.6450 & 0.6349 & 0.0073 & 0.2521 \\
\hline $\begin{array}{l}\text { Ln(Seatbelt: } \\
\text { MOTORWAYS) }\end{array}$ & 0.3279 & -0.3148 & -0.3397 & 0.5757 & -0.4896 & 0.0251 & -0.0090 & 0.5443 & 0.5364 & 0.5579 & -0.0492 & 0.1864 \\
\hline
\end{tabular}

\section{Correlation Coefficients for additional variables:}

\begin{tabular}{llll}
\hline \hline (408 obs): & Ln(URBAN) & Ln(LIVER) & Ln(PHYSICIANS) \\
\hline
\end{tabular}

\begin{tabular}{lrrr}
$\operatorname{Ln}($ URBAN $)$ & 1 & & \\
\hline & & & \\
$\operatorname{Ln}($ LIVER $)$ & -0.4011 & 1 & 1 \\
\hline Ln(PHYSICIANS) & -0.0652 & 0.2464 & \\
\hline
\end{tabular}

\begin{tabular}{lcc}
\hline & Ln(LIVER) & Ln(PHYSICIANS) \\
\hline $\begin{array}{l}\text { Ln(Seatbelt: URBAN) } \\
\text { (164 obs) }\end{array}$ & -0.3052 & 0.0312 \\
\hline $\begin{array}{l}\text { Ln(Seatbelt: RURAL) } \\
\text { (105 obs) }\end{array}$ & -0.2188 & 0.3320 \\
\hline
\end{tabular}


Table 7. Results for Occupant Fatalities/VKT Models ${ }^{\mathrm{a}}$

\begin{tabular}{|c|c|c|c|c|c|}
\hline & 1 (Base & & & & \\
\hline & Model) & 2 & 3 & 4 & 5 \\
\hline $\ln (\mathrm{Y})$ & $\begin{array}{c}-2.158 * * * \\
(0.642)\end{array}$ & $\begin{array}{c}-2.515 * * * \\
(0.737)\end{array}$ & $\begin{array}{c}-2.713 * * * \\
(0.734)\end{array}$ & $\begin{array}{c}-2.280 * * * \\
(0.646)\end{array}$ & $\begin{array}{c}-2.078 * * * \\
(0.708)\end{array}$ \\
\hline $\ln ($ YOUTH $)$ & $\begin{array}{c}13.279 * * * \\
(3.558)\end{array}$ & $\begin{array}{c}15.219^{* * *} \\
(4.058)\end{array}$ & $\begin{array}{c}15.833 * * * \\
(4.019)\end{array}$ & $\begin{array}{c}13.833 * * * \\
(3.596)\end{array}$ & $\begin{array}{c}12.851 * * * \\
(3.862)\end{array}$ \\
\hline $\begin{array}{l}\ln (\mathrm{YOUTH}) \\
* \ln (\mathrm{Y}) \\
\end{array}$ & $\begin{array}{c}-1.304^{* * * *} \\
(0.359) \\
\end{array}$ & $\begin{array}{c}-1.492 * * * \\
(0.409) \\
\end{array}$ & $\begin{array}{c}-1.540 * * * \\
(0.406) \\
\end{array}$ & $\begin{array}{c}-1.357 * * * \\
(0.367) \\
\end{array}$ & $\begin{array}{c}-1.245 * * * \\
(0.395) \\
\end{array}$ \\
\hline $\ln (\mathrm{VEH})$ & $\begin{array}{l}0.382 * * \\
(0.167) \\
\end{array}$ & $\begin{array}{c}0.477 * * * \\
(0.177)\end{array}$ & $\begin{array}{c}0.232 \\
(0.229) \\
\end{array}$ & $\begin{array}{c}0.253 \\
(0.206) \\
\end{array}$ & $\begin{array}{l}0.386^{*} \\
(0.226)\end{array}$ \\
\hline $\ln (\mathrm{RD})$ & $\begin{array}{c}-0.388 * * \\
(0.156)\end{array}$ & $\begin{array}{l}-0.258 \\
(0.167)\end{array}$ & $\begin{array}{c}-0.719 * * \\
(0.308)\end{array}$ & $\begin{array}{l}-0.358 \\
(0.244) \\
\end{array}$ & $\begin{array}{c}-0.416^{* *} \\
(0.175)\end{array}$ \\
\hline $\ln (\mathrm{VEH}) * \mathrm{t}$ & $\begin{array}{c}-0.012 * * * \\
(0.002)\end{array}$ & $\begin{array}{c}-0.012 * * * \\
(0.003)\end{array}$ & $\begin{array}{c}-0.010 * * * \\
(0.003)\end{array}$ & $\begin{array}{c}-0.009 * * * \\
(0.003)\end{array}$ & $\begin{array}{c}-0.011 * * * \\
(0.002)\end{array}$ \\
\hline $\ln (\mathrm{RD}) * \mathrm{t}$ & $\begin{array}{c}0.013 * * * \\
(0.002)\end{array}$ & $\begin{array}{c}0.013 * * * \\
(0.002)\end{array}$ & $\begin{array}{c}0.011 * * * \\
(0.004)\end{array}$ & $\begin{array}{c}0.010 * * * \\
(0.004)\end{array}$ & $\begin{array}{c}0.012 * * * \\
(0.002)\end{array}$ \\
\hline $\mathrm{t}$ & $\begin{array}{c}-0.014 \\
(0.015)\end{array}$ & $\begin{array}{l}-0.009 \\
(0.021)\end{array}$ & $\begin{array}{l}-0.017 \\
(0.023)\end{array}$ & $\begin{array}{l}-0.030^{*} \\
(0.017)\end{array}$ & $\begin{array}{l}-0.019 \\
(0.015)\end{array}$ \\
\hline VEHGROWTH & $\begin{array}{l}0.587^{* *} \\
(0.278)\end{array}$ & $\begin{array}{c}0.231 \\
(0.268) \\
\end{array}$ & $\begin{array}{c}.059 * * * \\
(0.388)\end{array}$ & $\begin{array}{l}0.670^{*} \\
(0.351)\end{array}$ & $\begin{array}{l}0.479^{*} \\
(0.271)\end{array}$ \\
\hline $\ln ($ ELDERLY) & $\begin{array}{c}0.061 \\
(0.220) \\
\end{array}$ & $\begin{array}{l}-0.090 \\
(0.245) \\
\end{array}$ & $\begin{array}{c}0.290 \\
(0.385) \\
\end{array}$ & $\begin{array}{c}0.141 \\
(0.242) \\
\end{array}$ & $\begin{array}{l}-0.112 \\
(0.226) \\
\end{array}$ \\
\hline $\ln (\mathrm{URBAN})$ & $\begin{array}{c}-0.091 \\
(0.346) \\
\end{array}$ & $\begin{array}{l}-0.080 \\
(0.352) \\
\end{array}$ & $\begin{array}{c}0.137 \\
(0.783) \\
\end{array}$ & $\begin{array}{c}0.150 \\
(0.792) \\
\end{array}$ & $\begin{array}{l}-0.064 \\
(0.392) \\
\end{array}$ \\
\hline $\ln ($ LIVER $)$ & & & $\begin{array}{l}0.099 * * \\
(0.050)\end{array}$ & & \\
\hline $\ln$ (PHYSICIANS) & & $\begin{array}{l}-0.303^{*} \\
(0.170) \\
\end{array}$ & & & \\
\hline $\ln (\mathrm{ALCOHOL})$ & & & & $\begin{array}{c}0.004 \\
(0.098)\end{array}$ & \\
\hline 2WHEELERS & & & & & $\begin{array}{c}0.001 \\
(0.004)\end{array}$ \\
\hline Constant & $\begin{array}{c}18.345 * * * \\
(5.913)\end{array}$ & $\begin{array}{c}19.433 * * * \\
(6.793)\end{array}$ & $\begin{array}{c}29.392 * * * \\
(10.489)\end{array}$ & $\begin{array}{c}20.323 * * \\
(9.240)\end{array}$ & $\begin{array}{c}17.516^{* * * *} \\
(6.167)\end{array}$ \\
\hline Adj. R-squared & 0.9601 & 0.9629 & 0.9542 & 0.9609 & 0.9624 \\
\hline Observations & 680 & 537 & 515 & 581 & 613 \\
\hline Countries & 32 & 29 & 30 & 30 & 31 \\
\hline $\begin{array}{l}\text { Elasticity with } \\
\text { respect to } \mathrm{Y}^{\mathrm{b}} \text { : }\end{array}$ & $\begin{array}{c}-0.011 \\
(0.130) \\
\end{array}$ & $\begin{array}{l}-0.059 \\
(0.112) \\
\end{array}$ & $\begin{array}{l}-0.179 \\
(0.136) \\
\end{array}$ & $\begin{array}{l}-0.046 \\
(0.144) \\
\end{array}$ & $\begin{array}{l}-0.028 \\
(0.132) \\
\end{array}$ \\
\hline $\begin{array}{l}\text { Elasticity with } \\
\text { respect to } \\
\text { YOUTH }^{\text {b }} \text { : }\end{array}$ & $\begin{array}{c}0.608^{* *} \\
(0.258)\end{array}$ & $\begin{array}{c}0.718 * * * \\
(0.254)\end{array}$ & $\begin{array}{c}0.870 * * * \\
(0.299)\end{array}$ & $\begin{array}{c}0.643^{* *} \\
(0.297)\end{array}$ & $\begin{array}{c}0.749 * * * \\
(0.229)\end{array}$ \\
\hline
\end{tabular}

*** Indicates $1 \%$ level of significance ** Indicates $5 \%$ level of significance

* Indicates $10 \%$ level of significance.

${ }^{a}$ Heteroskedasticity-corrected standard errors, clustered on country to allow for within panel autocorrelation, are given in parentheses. Country fixed effects were included in all regressions but are not displayed here.

${ }^{\mathrm{b}}$ Elasticities are evaluated at mean $\ln (\mathrm{Y})$ and $\ln (\mathrm{YOUTH})$ of Base Model sample: $\mathrm{Y}=\$ 16,630$ (1996 Int'l dollars), YOUTH $=0.1928$. For example, in Model 1 , the income elasticity of the occupant fatality rate $=$ $\partial \ln ($ Occupant fatalities $/ \mathrm{VKT}) / \partial \ln (\mathrm{Y})=-2.158-1.304 *(\ln (0.192781))=-0.011$. 
Table 8. Results for Pedestrian Fatalities/VKT Models ${ }^{\mathrm{a}}$

\begin{tabular}{|c|c|c|c|c|c|}
\hline & $\begin{array}{l}1 \text { (Base } \\
\text { Model) }\end{array}$ & 2 & 3 & 4 & 5 \\
\hline $\ln (Y)$ & $\begin{array}{l}-0.779 \\
(0.704) \\
\end{array}$ & $\begin{array}{l}-0.923 \\
(0.856)\end{array}$ & $\begin{array}{l}-1.757 * * \\
(0.837) \\
\end{array}$ & $\begin{array}{l}-0.912 \\
(0.823)\end{array}$ & $\begin{array}{l}-1.624 * * * \\
(0.610)\end{array}$ \\
\hline $\ln (\mathrm{YOUTH})$ & $\begin{array}{l}3.682 \\
(4.246)\end{array}$ & $\begin{array}{l}4.929 \\
(4.926)\end{array}$ & $\begin{array}{l}10.047 * * \\
(4.989)\end{array}$ & $\begin{array}{l}3.988 \\
(4.763)\end{array}$ & $\begin{array}{l}9.059 * * * \\
(3.501)\end{array}$ \\
\hline $\begin{array}{l}\ln (\mathrm{YOUTH}) \\
* \ln (\mathrm{Y})\end{array}$ & $\begin{array}{l}-0.319 \\
(0.424) \\
\end{array}$ & $\begin{array}{l}-0.442 \\
(0.502) \\
\end{array}$ & $\begin{array}{l}-0.950 * \\
(0.503) \\
\end{array}$ & $\begin{array}{l}-0.350 \\
(0.479) \\
\end{array}$ & $\begin{array}{l}-0.871 * * \\
(0.355) \\
\end{array}$ \\
\hline $\ln (\mathrm{VEH})$ & $\begin{array}{l}-0.392 * \\
(0.219) \\
\end{array}$ & $\begin{array}{l}-0.354^{*} \\
(0.198) \\
\end{array}$ & $\begin{array}{l}-0.367 \\
(0.266) \\
\end{array}$ & $\begin{array}{l}-0.436^{*} \\
(0.247) \\
\end{array}$ & $\begin{array}{l}-0.269 \\
(0.216) \\
\end{array}$ \\
\hline $\ln (\mathrm{RD})$ & $\begin{array}{l}-0.491 * \\
(0.268) \\
\end{array}$ & $\begin{array}{l}-0.583^{*} \\
(0.306) \\
\end{array}$ & $\begin{array}{l}-1.000^{* * *} \\
(0.259)\end{array}$ & $\begin{array}{l}-0.513 * \\
(0.306) \\
\end{array}$ & $\begin{array}{l}-0.533^{* *} \\
(0.264)\end{array}$ \\
\hline $\ln (\mathrm{VEH}) * \mathrm{t}$ & $\begin{array}{l}-0.006 \\
(0.004) \\
\end{array}$ & $\begin{array}{l}-0.004 \\
(0.004) \\
\end{array}$ & $\begin{array}{l}-0.005 \\
(0.004)\end{array}$ & $\begin{array}{l}-0.007 * \\
(0.004)\end{array}$ & $\begin{array}{l}-0.006^{*} \\
(0.004)\end{array}$ \\
\hline $\ln (\mathrm{RD}) * \mathrm{t}$ & $\begin{array}{l}0.010 * * \\
(0.004)\end{array}$ & $\begin{array}{l}0.010 * * \\
(0.004)\end{array}$ & $\begin{array}{l}0.009 * * \\
(0.004)\end{array}$ & $\begin{array}{l}0.012 * * \\
(0.005)\end{array}$ & $\begin{array}{l}0.011 * * * \\
(0.004)\end{array}$ \\
\hline $\mathrm{t}$ & $\begin{array}{l}-0.083 * * * \\
(0.025) \\
\end{array}$ & $\begin{array}{l}-0.108 * * * \\
(0.024)\end{array}$ & $\begin{array}{l}-0.092 * * * \\
(0.032) \\
\end{array}$ & $\begin{array}{l}-0.078 * * * \\
(0.023) \\
\end{array}$ & $\begin{array}{l}-0.101 * * * \\
(0.022)\end{array}$ \\
\hline VEHGROWTH & $\begin{array}{l}0.985 * * \\
(0.412)\end{array}$ & $\begin{array}{l}0.715 \\
(0.475)\end{array}$ & $\begin{array}{l}1.080 * * * \\
(0.341)\end{array}$ & $\begin{array}{l}1.179 * * \\
(0.516)\end{array}$ & $\begin{array}{l}0.965 * * * \\
(0.343)\end{array}$ \\
\hline $\ln ($ ELDERLY) & $\begin{array}{l}0.709 * * * \\
(0.259)\end{array}$ & $\begin{array}{l}0.374 * \\
(0.212)\end{array}$ & $\begin{array}{l}0.568 * \\
(0.343) \\
\end{array}$ & $\begin{array}{l}0.809 * * * \\
(0.303)\end{array}$ & $\begin{array}{l}0.522^{* *} \\
(0.243)\end{array}$ \\
\hline $\ln (\mathrm{URBAN})$ & $\begin{array}{l}1.003^{* *} \\
(0.447) \\
\end{array}$ & $\begin{array}{l}1.134 * * \\
(0.484)\end{array}$ & $\begin{array}{l}1.070 \\
(0.908)\end{array}$ & $\begin{array}{l}1.121 \\
(1.022)\end{array}$ & $\begin{array}{l}0.851 * * \\
(0.366)\end{array}$ \\
\hline $\ln (\mathrm{POP})$ & $\begin{array}{l}0.142 \\
(0.673)\end{array}$ & $\begin{array}{l}-0.652 \\
(0.642)\end{array}$ & $\begin{array}{l}0.669 \\
(0.657)\end{array}$ & $\begin{array}{l}-0.188 \\
(0.862)\end{array}$ & $\begin{array}{l}0.243 \\
(0.536)\end{array}$ \\
\hline $\ln ($ LIVER $)$ & & & $\begin{array}{l}0.220 * * * \\
(0.067)\end{array}$ & & \\
\hline $\ln ($ PHYSICIANS) & & $\begin{array}{l}-0.233 \\
(0.225)\end{array}$ & & & \\
\hline $\ln (\mathrm{ALCOHOL})$ & & & & $\begin{array}{c}0.164 \\
(0.155) \\
\end{array}$ & \\
\hline 2WHEELERS & & & & & $\begin{array}{l}-0.007 \\
(0.005)\end{array}$ \\
\hline Constant & $\begin{array}{l}11.570 \\
(11.592) \\
\end{array}$ & $\begin{array}{l}25.623 * * \\
(11.804) \\
\end{array}$ & $\begin{array}{l}17.342 \\
(13.394) \\
\end{array}$ & $\begin{array}{l}18.434 \\
(15.194) \\
\end{array}$ & $\begin{array}{c}17.292 \\
(11.505) \\
\end{array}$ \\
\hline Adj. R-squared & 0.9613 & 0.9630 & 0.9608 & 0.9603 & 0.9638 \\
\hline Observations & 680 & 537 & 515 & 581 & 613 \\
\hline Countries & 32 & 29 & 30 & 30 & 31 \\
\hline $\begin{array}{l}\text { Elasticity with } \\
\text { respect to } \mathrm{Y}^{\mathrm{b}} \text { : }\end{array}$ & $\begin{array}{l}-0.254^{*} \\
(0.145) \\
\end{array}$ & $\begin{array}{l}-0.195 \\
(0.167) \\
\end{array}$ & $\begin{array}{l}-0.193 \\
(0.204) \\
\end{array}$ & $\begin{array}{l}-0.335 \\
(0.205) \\
\end{array}$ & $\begin{array}{l}-0.190 \\
(0.157) \\
\end{array}$ \\
\hline $\begin{array}{l}\text { Elasticity with } \\
\text { respect to } \\
\text { YOUTH }^{\text {b }}\end{array}$ & $\begin{array}{l}0.585 * * \\
(0.289)\end{array}$ & $\begin{array}{l}0.635 * * \\
(0.282)\end{array}$ & $\begin{array}{l}0.815 * * \\
(0.329)\end{array}$ & $\begin{array}{l}0.584 * \\
(0.325)\end{array}$ & $\begin{array}{l}0.592 * \\
(0.313)\end{array}$ \\
\hline
\end{tabular}

*** Indicates $1 \%$ level of significance $* *$ Indicates $5 \%$ level of significance

* Indicates $10 \%$ level of significance

${ }^{a}$ Heteroskedasticity-corrected standard errors, clustered on country to allow for within panel autocorrelation, are given in parentheses. Country fixed effects were included in all regressions but are not displayed here.

${ }^{\mathrm{b}}$ Elasticities are evaluated at mean $\ln (\mathrm{Y})$ and $\ln (\mathrm{YOUTH})$ of Base Model sample: $\mathrm{Y}=\$ 16,630$ (1996 Int'1 dollars), YOUTH $=0.1928$ 


\section{Appendix A \\ Data Sources}

Data for this analysis were compiled for 32 high-income countries covering the years 1964-2002. A complete list of countries included in the estimation of (11) and (12) is given in Table 3. Table 5 provides descriptive statistics for the variables in the sample.

The primary sources of transport and road safety related variables are the OECD International Road Traffic Accident Database (IRTAD) and the International Road Federation World Road Statistics yearbooks (IRF, various years). However, these series were checked against and supplemented by data from numerous national statistical agencies and other sources. Health related data come primarily from OECD Health Data 2003, the World Health Organization (WHO), and World Drink Trends 2000. Total population and population cohorts are taken from the U.S. Census International Database, the United Nations Population Database, IRTAD, and national statistical agencies.

Figures on urban population come from the World Bank World Development Indicators (WDI). A detailed description of all data sources for each variable and country is given in Appendices A and B of Kopits (2004).

Long time series of total vehicle kilometers traveled are difficult to obtain, even for several high-income countries. In an effort to increase the sample size, the official VKT statistics were extended using predicted values from regressions of VKT on total motor vehicle fuel consumption (petrol and diesel). ${ }^{38}$ In total, the predicted values were

\footnotetext{
${ }^{38}$ To do this, we estimated the following reduced form VKT equation for each country: $\mathrm{VKT}_{\mathrm{t}}=\mathrm{a}+\mathrm{b}$ PETROL $_{\mathrm{t}}+\mathrm{c}$ DIESEL $_{\mathrm{t}}+\mathrm{d} \mathrm{t}+\varepsilon_{\mathrm{t}}$, where PETROL $\mathrm{t}=$ total petrol consumed in road vehicles in year $\mathrm{t}, \mathrm{DIESEL}_{\mathrm{t}}=$ total diesel fuel consumed in road vehicles in year $\mathrm{t}$, and $\mathrm{t}$ is a linear time trend. PETROL and DIESEL (measured in thousands of metric tons) come primarily from the IRF World Road Statistics yearbooks. These series were cross-checked and supplemented by data from OECD Energy
} 
used to extend the base VKT data for 17 countries, increasing the sample size by 126

observations (from 704 to 830 ). ${ }^{39}$

Real per capita GDP is measured in 1996 international dollars. This series comes

from the Penn World Tables 6.1 (Heston et al., 2002) for 1963-2000 and was extended to 2002 using per capita GDP growth rates (OECD National Accounts). ${ }^{40}$

Statistics (various editions) and national sources where appropriate. See Appendix B of Kopits (2004) for a complete discussion and for the estimation results for equations in Table 2 using the base VKT data.

${ }^{39}$ Extrapolating the VKT series adds additional measurement error to the dependent variable. However, since all computed standard errors are already heteroskedasticity-corrected, no additional variance correction is necessary to account for the use of predicted data.

${ }^{40}$ Kopits (2004) describes this extension in detail and presents regression results from equations shown in Table 2 using income series from Kopits and Cropper (2005) (measured in 1985 international dollars) as well. 


\section{Appendix B Importance of Seatbelt Usage}

Tables B.1 and B.2 summarize the estimates of the vehicle occupant and nonoccupant fatality rate with the inclusion of the seatbelt variables. Lack of data on seatbelt usage rates results in the models in Tables B.1 and B.2 being estimated with fewer countries and fewer years of data per country than the models in Tables 7 and $8 .{ }^{41}$ One should, therefore, not expect results as robust as those in Tables 7 and 8 . In addition, all two-wheeler deaths are now included in the dependent variable in Table B.2 (nonoccupant fatalities/VKT). In general, the signs of the non-seatbelt variables in Tables B.1 and B.2 agree with those in Tables 7 and 8, although far fewer variables are statistically significant.

We measure national seatbelt usage by the percentage of car drivers wearing seatbelts on three road types: urban roads, rural roads, and motorways. ${ }^{42}$ The elasticity of vehicle occupant deaths/VKT with respect to the urban seatbelt wearing rate is found to be -0.053 (0.028) (Model 7 in Table B.1). ${ }^{43}$ The beneficial impact of seatbelts is, however, twice as large on rural roads, and the magnitude and significance (at the $1 \%$ level) of the coefficient on rural seatbelt wearing rate $(-0.111(0.021)$ (Model 8)) remains stable when other controls are added to the model (see Kopits (2004)). ${ }^{44}$ When wearing rates on motorways only enters the model, the elasticity falls slightly in magnitude to -

\footnotetext{
${ }^{41}$ The number of countries with data on seatbelt wearing rates on urban roads, rural roads, and motorways (as well as data for all other variables in the Base Model (Model 1)) is 20, 16, and 15, respectively. Consequently, the number of observations falls (from 680 in the Base Model) to 261, 198, and 191, respectively. Table 3 provides a list of the countries included in each subset.

${ }^{42}$ Rural roads include motorways.

${ }^{43}$ This result is identical to Cohen and Einav's (2003) recent estimates of the effect of seatbelt usage on vehicle occupant deaths per vehicle mile traveled in the U.S. during 1983-1997.

${ }^{44}$ If Model 7 is re-estimated using only those countries for which the rural wearing rates are available (dropping Canada, Japan, South Korea, and the United States from the sample), the impact on occupant deaths/VKT decreases to $-0.063(0.032)$ and becomes statistically significant at the $5 \%$ level.
} 
0.092 (0.038) (Model 9). It is not surprising that the effect is similar to rural roads since motorways are a subset of rural roads.

There may be some partial offsetting behavior affecting the safety benefits to vehicle occupants (e.g., seatbelt wearing rates may be higher under riskier driving conditions). Examining the extent to which this is influencing the effect of seatbelt use on the occupant fatality rate requires more detailed data. The negative coefficient on seatbelt usage can only reassure us that the beneficial effects of seatbelt use to vehicle occupants were not completely offset by changes in driver behavior.

We attempt to account for the potential endogeneity of the seatbelt variable ${ }^{45}$ by instrumenting seatbelt usage with a variable equal to the number of years since the first mandatory seatbelt law (for front passengers) was passed. Using this instrument (for Models 7, 8, and 9), the magnitude of the elasticity of the occupant fatality rate did increase for both urban roads and motorways to $-0.219(0.162)$ and $-0.166(0.150)$, respectively, but the effect is statistically insignificant for all three road types. ${ }^{46,47}$ Some researchers (including Cohen and Einav (2003) who mention also finding an insignificant result with a similar instrument) suggest that this result supports the hypothesis that the effects of seatbelt laws are immediate and permanent.

\footnotetext{
${ }^{45}$ Increased seatbelt usage is expected to decrease the occupant fatality rate. However, if as hypothesized by Peltzman (1975), the increased driver protection produces more careless driving, the safety benefits to belted drivers could be offset by increased risk to other vehicle occupants, perhaps even causing the fatality rate to rise. On the other hand, the impact of seatbelt use could be understated if people increase their usage in risky areas.

${ }^{46}$ The elasticity of the occupant fatality rate with respect to the rural seatbelt wearing rate becomes 0.084 (0.109).

${ }^{47}$ Cohen and Einav (2003) also found the elasticity of occupant deaths per vehicle mile traveled with respect to seatbelt usage doubles (to $-0.133(0.047)$ ) when they instrument seatbelt usage with dummy variables indicating the presence of a mandatory seatbelt law and type of enforcement. Their results are discussed in Appendix A. Since mandatory seatbelt laws did not change over the time period of some of the panels included in our sample (and data on the type of enforcement is not available for all countries), replicating Cohen and Einav's instrumental variables estimation strategy is not possible here.
} 
In the case of non-occupants, the coefficient on seatbelt usage is consistently small and insignificant across all specifications in Table B.2. ${ }^{48}$ Since seatbelt usage can only affect the non-occupant deaths indirectly as a result of increased risk taking by belted drivers, the insignificance of this variable suggests there is no evidence of such compensating behavior. ${ }^{49}$ This result is inconsistent with Cohen and Einav's (2003) fixed effects estimates that show a significant, negative effect of seatbelt usage on nonoccupant fatality rates. The authors claim the beneficial effect is a result of increased safety consciousness of belted drivers, although once they instrument for seatbelt usage, their coefficient becomes small and insignificant (-0.042 (0.121)) as well.

Finally, the estimated elasticities of the non-occupant fatality rate with respect to several other control variables become insignificant in the Table B. 2 specifications. As in the case of vehicle occupants, the change in magnitude and significance of some of these elasticities in this smaller sample may be due to multicollinearity issues.

\footnotetext{
${ }^{48}$ This result is robust to the inclusion of other controls variables: PHYSICIANS, etc. (Kopits, 2004), ${ }^{49}$ Some studies have offered modest evidence of offsetting driver behavior resulting from seatbelt usage and seatbelt laws (Garbacz, 1992; Risa, 1994; Sen, 2001) but Cohen and Einav (2003) show have the positive effect on non-occupant fatalities disappears after controlling for state fixed effects.
} 
Table B.1. Results for Occupant Fatalities/VKT Models - Seatbelt Usage ${ }^{\text {a }}$

\begin{tabular}{|c|c|c|c|c|c|}
\hline & $\begin{array}{l}1 \text { (Base } \\
\text { Model) }\end{array}$ & $\begin{array}{l}\text { (Base, excl } \\
\text { 2wheeler } \\
\text { deaths) }\end{array}$ & 7 & 8 & 9 \\
\hline $\ln (\mathrm{Y})$ & $\begin{array}{c}-2.158 * * * \\
(0.642)\end{array}$ & $\begin{array}{c}-1.871 * * * \\
(0.620)\end{array}$ & $\begin{array}{l}-1.157 \\
(1.039) \\
\end{array}$ & $\begin{array}{l}-1.142 \\
(1.656) \\
\end{array}$ & $\begin{array}{l}-1.129 \\
(1.027)\end{array}$ \\
\hline $\ln (\mathrm{YOUTH})$ & $\begin{array}{c}13.279 * * * \\
(3.558)\end{array}$ & $\begin{array}{c}11.807 * * * \\
(3.945)\end{array}$ & $\begin{array}{l}10.94 * \\
(6.152)\end{array}$ & $\begin{array}{c}9.221 \\
(9.604)\end{array}$ & $\begin{array}{l}12.545^{*} \\
(6.495)\end{array}$ \\
\hline $\begin{array}{l}\ln (\text { YOUTH }) \\
* \ln (Y)\end{array}$ & $\begin{array}{c}-1.304 * * * \\
(0.359)\end{array}$ & $\begin{array}{c}-1.141 * * * \\
(0.396)\end{array}$ & $\begin{array}{l}-1.035^{*} \\
(0.630)\end{array}$ & $\begin{array}{l}-0.916 \\
(0.972) \\
\end{array}$ & $\begin{array}{l}-1.142 * \\
(0.635)\end{array}$ \\
\hline $\ln (\mathrm{VEH})$ & $\begin{array}{c}0.382 * * \\
(0.167)\end{array}$ & $\begin{array}{c}0.170 \\
(0.189) \\
\end{array}$ & $\begin{array}{c}0.222 \\
(0.302) \\
\end{array}$ & $\begin{array}{c}0.214 \\
(0.331) \\
\end{array}$ & $\begin{array}{c}-0.357 \\
(0.390)\end{array}$ \\
\hline $\ln (\mathrm{RD})$ & $\begin{array}{c}-0.388 * * \\
(0.156)\end{array}$ & $\begin{array}{c}-0.403 * * * \\
(0.145)\end{array}$ & $\begin{array}{c}-0.837 * * \\
(0.404)\end{array}$ & $\begin{array}{l}-0.845^{*} \\
(0.465)\end{array}$ & $\begin{array}{c}-0.381 \\
(0.509)\end{array}$ \\
\hline $\ln (\mathrm{VEH}) * \mathrm{t}$ & $\begin{array}{c}-0.012 * * * \\
(0.002)\end{array}$ & $\begin{array}{c}-0.011 * * * \\
(0.002)\end{array}$ & $\begin{array}{c}-0.010 * * \\
(0.004)\end{array}$ & $\begin{array}{c}-0.014 * * \\
(0.007) \\
\end{array}$ & $\begin{array}{l}-0.003 \\
(0.009)\end{array}$ \\
\hline $\ln (\mathrm{RD}) * \mathrm{t}$ & $\begin{array}{c}0.013 * * * \\
(0.002)\end{array}$ & $\begin{array}{c}0.010 * * * \\
(0.002)\end{array}$ & $\begin{array}{c}0.011 * * \\
(0.004)\end{array}$ & $\begin{array}{l}0.014 * * \\
(0.007)\end{array}$ & $\begin{array}{c}0.002 \\
(0.009) \\
\end{array}$ \\
\hline $\mathrm{t}$ & $\begin{array}{c}-0.014 \\
(0.015) \\
\end{array}$ & $\begin{array}{c}0.006 \\
(0.015) \\
\end{array}$ & $\begin{array}{l}-0.027 \\
(0.024) \\
\end{array}$ & $\begin{array}{c}0.002 \\
(0.038) \\
\end{array}$ & $\begin{array}{c}-0.013 \\
(0.034) \\
\end{array}$ \\
\hline VEHGROWTH & $\begin{array}{c}0.587 * * \\
(0.278)\end{array}$ & $\begin{array}{c}0.773 * * * \\
(0.277)\end{array}$ & $\begin{array}{l}0.936^{*} \\
(0.535)\end{array}$ & $\begin{array}{l}-0.015 \\
(0.414)\end{array}$ & $\begin{array}{c}0.261 \\
(0.368)\end{array}$ \\
\hline $\ln ($ ELDERLY) & $\begin{array}{c}0.061 \\
(0.220) \\
\end{array}$ & $\begin{array}{c}0.154 \\
(0.195) \\
\end{array}$ & $\begin{array}{c}0.376 \\
(0.247) \\
\end{array}$ & $\begin{array}{c}0.958 \\
(0.608) \\
\end{array}$ & $\begin{array}{l}0.548 * * \\
(0.237)\end{array}$ \\
\hline $\ln (\mathrm{URBAN})$ & $\begin{array}{c}-0.091 \\
(0.346)\end{array}$ & $\begin{array}{c}0.236 \\
(0.387)\end{array}$ & $\begin{array}{c}1.158 \\
(0.839)\end{array}$ & $\begin{array}{c}0.877 \\
(1.249) \\
\end{array}$ & $\begin{array}{l}1.122 * * \\
(0.540)\end{array}$ \\
\hline \multicolumn{6}{|c|}{$\ln ($ Seatbelt wearing rates $):$} \\
\hline Urban roads & & & $\begin{array}{l}-0.053^{*} \\
(0.028)\end{array}$ & & \\
\hline Rural roads & & & & $\begin{array}{c}-0.111 * * * \\
(0.021)\end{array}$ & \\
\hline Motorways & & & & & $\begin{array}{c}-0.092 * * \\
(0.038)\end{array}$ \\
\hline Constant & $\begin{array}{c}18.345 * * * \\
(5.913)\end{array}$ & $\begin{array}{c}17.480 * * * \\
(6.138)\end{array}$ & $\begin{array}{c}12.125 \\
(11.463)\end{array}$ & $\begin{array}{c}13.679 \\
(16.575)\end{array}$ & $\begin{array}{c}16.786 \\
(10.563)\end{array}$ \\
\hline Adj. R-squared & 0.9601 & 0.9481 & 0.9712 & 0.9666 & 0.9744 \\
\hline Observations & 680 & 636 & 261 & 198 & 191 \\
\hline Countries & 32 & 30 & 20 & 16 & 15 \\
\hline $\begin{array}{l}\text { Elasticity with } \\
\text { respect to } \mathrm{Y}^{\mathrm{b}} \text { : }\end{array}$ & $\begin{array}{c}-0.011 \\
(0.130)\end{array}$ & $\begin{array}{c}0.008 \\
(0.157)\end{array}$ & $\begin{array}{c}0.547 * * \\
(0.237)\end{array}$ & $\begin{array}{c}0.366 \\
(0.394)\end{array}$ & $\begin{array}{c}0.751 * * \\
(0.315)\end{array}$ \\
\hline $\begin{array}{l}\text { Elasticity with } \\
\text { respect to } \\
\text { YOUTH }^{\text {b }} \text {. }\end{array}$ & $\begin{array}{c}0.608 * * \\
(0.258)\end{array}$ & $\begin{array}{c}0.717 * * \\
(0.315)\end{array}$ & $\begin{array}{c}0.882 * * * \\
(0.296)\end{array}$ & $\begin{array}{c}0.320 \\
(0.693)\end{array}$ & $\begin{array}{c}1.448 * * * \\
(0.370)\end{array}$ \\
\hline $\begin{array}{l}\text { Elasticity with } \\
\text { respect to } \mathrm{Y}^{\mathrm{c}} \text { : }\end{array}$ & $\begin{array}{l}-0.000 \\
(0.129)\end{array}$ & $\begin{array}{c}0.017 \\
(0.158)\end{array}$ & $\begin{array}{c}0.634 * * \\
(0.248)\end{array}$ & $\begin{array}{c}0.443 \\
(0.401)\end{array}$ & $\begin{array}{c}0.760 * * \\
(0.316)\end{array}$ \\
\hline $\begin{array}{l}\text { Elasticity with } \\
\text { respect to } \\
\text { YOUTH }^{c} \text { : }\end{array}$ & $\begin{array}{c}0.582 * * \\
(0.257)\end{array}$ & $\begin{array}{c}0.694 * * \\
(0.313)\end{array}$ & $\begin{array}{c}0.692 * * \\
(0.308)\end{array}$ & $\begin{array}{c}0.152 \\
(0.682)\end{array}$ & $\begin{array}{c}1.425 * * * \\
(0.358)\end{array}$ \\
\hline
\end{tabular}

*** Indicates $1 \%$ level of significance $* *$ Indicates $5 \%$ level of significance

* Indicates $10 \%$ level of significance

${ }^{\text {a }}$ Heteroskedasticity-corrected standard errors, clustered on country to allow for within panel autocorrelation, are given in parentheses. Country fixed effects were included in all regressions but are not displayed here.

${ }^{\mathrm{b}}$ Elasticities are evaluated at mean $\ln (\mathrm{Y})$ and $\ln ($ YOUTH) of Base Model sample: $\mathrm{Y}=\$ 16,630$ (1996 Int'l dollars), YOUTH $=0.1928$. 
${ }^{c}$ Elasticities are evaluated at mean $\ln (\mathrm{Y})$ and $\ln (\mathrm{YOUTH})$ of Model 6 sample: $\mathrm{Y}=\$ 19,980$ (1996 Int'l dollars), YOUTH $=0.1777$. 
Table B.2. Results for Non-Occupant Fatalities/VKT Models - Seatbelt Usage ${ }^{\text {a }}$

\begin{tabular}{|c|c|c|c|c|c|}
\hline & $\begin{array}{l}1 \text { (Base } \\
\text { Model) }\end{array}$ & $\begin{array}{l}\text { (Base, incl. } \\
\text { 2wheeler } \\
\text { deaths) }\end{array}$ & 7 & 8 & 9 \\
\hline $\ln (\mathrm{Y})$ & $\begin{array}{l}-0.779 \\
(0.704)\end{array}$ & $\begin{array}{c}-2.564 * * * \\
(0.750)\end{array}$ & $\begin{array}{c}-4.068 * * \\
(1.675) \\
\end{array}$ & $\begin{array}{c}-5.096 * * * \\
(1.741) \\
\end{array}$ & $\begin{array}{c}-5.505 * * * \\
(1.197) \\
\end{array}$ \\
\hline $\ln (\mathrm{YOUTH})$ & $\begin{array}{c}3.682 \\
(4.246) \\
\end{array}$ & $\begin{array}{c}16.086^{* * *} * \\
(3.948)\end{array}$ & $\begin{array}{c}26.969 * * * \\
(9.904)\end{array}$ & $\begin{array}{c}29.462 * * * \\
(9.932)\end{array}$ & $\begin{array}{c}37.163^{* * *} * \\
(7.459)\end{array}$ \\
\hline $\begin{array}{l}\ln (\mathrm{YOUTH}) \\
* \ln (\mathrm{Y})\end{array}$ & $\begin{array}{l}-0.319 \\
(0.424)\end{array}$ & $\begin{array}{c}-1.556 * * * \\
(0.400)\end{array}$ & $\begin{array}{c}-2.656 * * * \\
(0.998)\end{array}$ & $\begin{array}{c}-2.943 * * * \\
(0.999)\end{array}$ & $\begin{array}{c}-3.642 * * * \\
(0.732)\end{array}$ \\
\hline $\ln (\mathrm{VEH})$ & $\begin{array}{l}-0.392 * \\
(0.219)\end{array}$ & $\begin{array}{l}-0.095 \\
(0.245)\end{array}$ & $\begin{array}{c}-0.060 \\
(0.226)\end{array}$ & $\begin{array}{c}-0.078 \\
(0.283)\end{array}$ & $\begin{array}{l}-0.520 \\
(0.341)\end{array}$ \\
\hline $\ln (\mathrm{RD})$ & $\begin{array}{l}-0.491 * \\
(0.268) \\
\end{array}$ & $\begin{array}{l}-0.237 \\
(0.247) \\
\end{array}$ & $\begin{array}{c}0.494 \\
(0.400) \\
\end{array}$ & $\begin{array}{l}0.640 * \\
(0.375) \\
\end{array}$ & $\begin{array}{l}0.726^{*} \\
(0.436) \\
\end{array}$ \\
\hline $\ln (\mathrm{VEH}) * \mathrm{t}$ & $\begin{array}{l}-0.006 \\
(0.004) \\
\end{array}$ & $\begin{array}{l}-0.005 \\
(0.003)\end{array}$ & $\begin{array}{c}0.006 \\
(0.005) \\
\end{array}$ & $\begin{array}{l}-0.003 \\
(0.007) \\
\end{array}$ & $\begin{array}{c}0.008 \\
(0.007) \\
\end{array}$ \\
\hline $\ln (\mathrm{RD}) * \mathrm{t}$ & $\begin{array}{c}0.010 * * \\
(0.004)\end{array}$ & $\begin{array}{c}0.007 * * \\
(0.003)\end{array}$ & $\begin{array}{l}-0.003 \\
(0.006) \\
\end{array}$ & $\begin{array}{c}0.002 \\
(0.006) \\
\end{array}$ & $\begin{array}{l}-0.008 \\
(0.008) \\
\end{array}$ \\
\hline $\mathrm{t}$ & $\begin{array}{c}-0.083 * * * \\
(0.025)\end{array}$ & $\begin{array}{c}-0.076^{* * *} * \\
(0.028)\end{array}$ & $\begin{array}{c}-0.131 * * * \\
(0.017)\end{array}$ & $\begin{array}{l}-0.062 \\
(0.051) \\
\end{array}$ & $\begin{array}{c}-0.104 * * * \\
(0.030)\end{array}$ \\
\hline VEHGROWTH & $\begin{array}{c}0.985 * * \\
(0.412)\end{array}$ & $\begin{array}{c}0.886 * * \\
(0.359)\end{array}$ & $\begin{array}{c}0.823 * * * \\
(0.303)\end{array}$ & $\begin{array}{c}0.843 \\
(0.523)\end{array}$ & $\begin{array}{c}0.552 \\
(0.357)\end{array}$ \\
\hline $\ln ($ ELDERLY) & $\begin{array}{c}0.709 * * * \\
(0.259)\end{array}$ & $\begin{array}{l}0.634 * * \\
(0.253)\end{array}$ & $\begin{array}{c}0.492 * * * \\
(0.130)\end{array}$ & $\begin{array}{c}0.344 \\
(0.513) \\
\end{array}$ & $\begin{array}{c}0.396^{* * *} \\
(0.122)\end{array}$ \\
\hline $\ln (\mathrm{URBAN})$ & $\begin{array}{l}1.003 * * \\
(0.447)\end{array}$ & $\begin{array}{c}0.549 \\
(0.409) \\
\end{array}$ & $\begin{array}{c}0.530 \\
(0.629) \\
\end{array}$ & $\begin{array}{l}-0.663 \\
(0.769) \\
\end{array}$ & $\begin{array}{l}-0.355 \\
(0.753) \\
\end{array}$ \\
\hline$\underline{\ln (\mathrm{POP})}$ & $\begin{array}{c}0.142 \\
(0.673) \\
\end{array}$ & $\begin{array}{l}0.741 * \\
(0.431)\end{array}$ & $\begin{array}{c}0.734 \\
(0.735) \\
\end{array}$ & $\begin{array}{c}2.817 * * \\
(1.244)\end{array}$ & $\begin{array}{c}0.821 \\
(1.683) \\
\end{array}$ \\
\hline \multicolumn{6}{|c|}{ ln(Seatbelt wearing rates): } \\
\hline Urban roads & & & $\begin{array}{c}0.003 \\
(0.022)\end{array}$ & & \\
\hline Rural roads & & & & $\begin{array}{l}-0.008 \\
(0.021)\end{array}$ & \\
\hline Motorways & & & & & $\begin{array}{c}0.024 \\
(0.022)\end{array}$ \\
\hline Constant & $\begin{array}{c}11.570 \\
(11.592) \\
\end{array}$ & $\begin{array}{l}14.517 \\
(9.372) \\
\end{array}$ & $\begin{array}{c}19.811 \\
(22.584) \\
\end{array}$ & $\begin{array}{c}-0.636 \\
(26.298) \\
\end{array}$ & $\begin{array}{l}41.425^{*} \\
(24.984) \\
\end{array}$ \\
\hline Adj. R-squared & 0.9613 & 0.9614 & 0.9848 & 0.9819 & 0.9857 \\
\hline Observations & 680 & 636 & 261 & 198 & 191 \\
\hline Countries & 32 & 30 & 20 & 16 & 15 \\
\hline $\begin{array}{l}\text { Elasticity with } \\
\text { respect to } \mathrm{Y}^{\mathrm{b}} \text { : }\end{array}$ & $\begin{array}{l}-0.254^{*} \\
(0.145)\end{array}$ & $\begin{array}{l}-0.003 \\
(0.214) \\
\end{array}$ & $\begin{array}{c}0.304 * * * \\
(0.116)\end{array}$ & $\begin{array}{l}-0.251 \\
(0.323)\end{array}$ & $\begin{array}{c}0.490 * * * \\
(0.124)\end{array}$ \\
\hline $\begin{array}{l}\text { Elasticity with } \\
\text { respect to YOUTH }{ }^{\text {b. }} \text { : }\end{array}$ & $\begin{array}{l}0.585 * * \\
(0.289)\end{array}$ & $\begin{array}{c}0.964 * * * \\
(0.266)\end{array}$ & $\begin{array}{c}1.158 * * * \\
(0.311)\end{array}$ & $\begin{array}{c}0.858 * * \\
(0.401)\end{array}$ & $\begin{array}{c}1.770 * * * \\
(0.381)\end{array}$ \\
\hline $\begin{array}{l}\text { Elasticity with } \\
\text { respect to } \mathrm{Y}^{\mathrm{c}} \text { : }\end{array}$ & $\begin{array}{l}-0.252^{*} \\
(0.145) \\
\end{array}$ & $\begin{array}{c}0.010 \\
(0.213) \\
\end{array}$ & $\begin{array}{c}0.326^{* * *} \\
(0.114)\end{array}$ & $\begin{array}{l}-0.227 \\
(0.322) \\
\end{array}$ & $\begin{array}{c}0.521 * * * \\
(0.125)\end{array}$ \\
\hline $\begin{array}{l}\text { Elasticity with } \\
\text { respect to YOUTH }\end{array}$ & $\begin{array}{l}0.579 * * \\
(0.286)\end{array}$ & $\begin{array}{c}0.933 * * * \\
(0.265)\end{array}$ & $\begin{array}{c}1.104 * * * \\
(0.298)\end{array}$ & $\begin{array}{l}0.798 * * \\
(0.390)\end{array}$ & $\begin{array}{c}1.697 * * * \\
(0.368)\end{array}$ \\
\hline
\end{tabular}

*** Indicates $1 \%$ level of significance ** Indicates $5 \%$ level of significance * Indicates $10 \%$ level of significance

${ }^{a}$ Heteroskedasticity-corrected standard errors, clustered on country to allow for within panel autocorrelation, are given in parentheses. Country fixed effects were included in all regressions but are not displayed here.

${ }^{\mathrm{b}}$ Elasticities are evaluated at mean $\ln (\mathrm{Y})$ and $\ln (\mathrm{YOUTH})$ of Base Model sample: $\mathrm{Y}=\$ 16,630$ (1996 Int'l dollars), YOUTH $=0.1928$.

${ }^{c}$ Elasticities are evaluated at mean $\ln (\mathrm{Y})$ and $\ln (\mathrm{YOUTH})$ of Model 6 sample: $\mathrm{Y}=\$ 19,980$ (1996 Int'l dollars), YOUTH $=0.1777$. 